\title{
Recent Advances in Oncolytic Virotherapy and Immunotherapy for Glioblastoma: A Glimmer of Hope in the Search for an Effective Therapy?
}

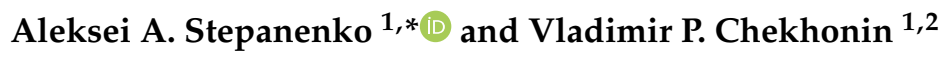 \\ 1 Department of Fundamental and Applied Neurobiology, V. P. Serbsky National Medical Research Center for \\ Psychiatry and Narcology, the Ministry of Health of the Russian Federation, Kropotkinsky lane 23, \\ 119034 Moscow, Russia; chekhoninnew@yandex.ru \\ 2 Department of Medical Nanobiotechnologies, Medico-Biological Faculty, N. I. Pirogov Russian National \\ Research Medical University, the Ministry of Health of the Russian Federation, Ostrovitianov str. 1, \\ 117997 Moscow, Russia \\ * Correspondence: a.a.stepanenko@gmail.com
}

Received: 7 November 2018; Accepted: 29 November 2018; Published: 5 December 2018

\begin{abstract}
To date, no targeted drugs, antibodies or combinations of chemotherapeutics have been demonstrated to be more efficient than temozolomide, or to increase efficacy of standard therapy (surgery, radiotherapy, temozolomide, steroid dexamethasone). According to recent phase III trials, standard therapy may ensure a median overall survival of up to 18-20 months for adult patients with newly diagnosed glioblastoma. These data explain a failure of positive non-controlled phase II trials to predict positive phase III trials and should result in revision of the landmark Stupp trial as a historical control for median overall survival in non-controlled trials. A high rate of failures in clinical trials and a lack of effective chemotherapy on the horizon fostered the development of conceptually distinct therapeutic approaches: dendritic cell/peptide immunotherapy, chimeric antigen receptor (CAR) T-cell therapy and oncolytic virotherapy. Recent early phase trials with the recombinant adenovirus DNX-2401 (Ad5-delta24-RGD), polio-rhinovirus chimera (PVSRIPO), parvovirus H-1 (ParvOryx), Toca 511 retroviral vector with 5-fluorocytosine, heat shock protein-peptide complex-96 (HSPPC-96) and dendritic cell vaccines, including DCVax-L vaccine, demonstrated that subsets of patients with glioblastoma/glioma may benefit from oncolytic virotherapy/immunotherapy ( $>3$ years of survival after treatment). However, large controlled trials are required to prove efficacy of next-generation immunotherapeutics and oncolytic vectors.
\end{abstract}

Keywords: immunotherapy; oncolytic virotherapy; temozolomide; targeted drugs; glioma; dendritic cell vaccine; radiotherapy; TTFields; PD-L1; bevacizumab

\section{Introduction}

Despite aggressive multimodal therapy (surgery, radiation, a genotoxic drug temozolomide, steroid dexamethasone, TTFields, lomustine, bevacizumab, re-irradiation, etc.), survival of adult patients with newly diagnosed and recurrent glioblastoma (grade IV malignant glioma) is usually less than 18-20 months [1-3] and 8-12 months [4-7], respectively. Over the last decade, high expectations were placed on targeted drug therapy, which was hoped to provide tumor growth control and further improvement in survival rates. However, to date, no molecularly targeted drug/antibody or combinations of small molecule inhibitors have been demonstrated to be more efficient than temozolomide (TMZ) or to increase efficacy of standard therapy in patients with primary/recurrent glioblastoma. A high rate of failures in clinical trials (Figure 1) and a lack of effective targeted therapy on the horizon have fostered the development of conceptually distinct therapeutic approaches such as 
cellular/peptide immunotherapy and oncolytic virotherapy. Next-generation immunotherapeutics and replication-competent genetically engineered oncolytic viruses demonstrated high efficacy in preclinical models (e.g., [8-12]). Recent early phase trials with the recombinant adenovirus DNX-2401 (Ad5-delta24-RGD) [13], polio-rhinovirus chimera (PVSRIPO) [14], parvovirus H-1 (ParvOryx) [15], Toca 511 retroviral vector with 5-fluorocytosine [16], heat shock protein-peptide complex-96 (HSPPC-96) vaccine $[17,18]$, cytomegalovirus pp65 RNA-pulsed dendritic cells $[8,19]$, and a large phase III trial of an autologous tumor lysate-pulsed dendritic cell vaccine (DCVax-L) [20], have demonstrated that subsets of recurrent glioblastoma/glioma patients may significantly benefit from oncolytic virotherapy or dendritic cell-/peptide-based vaccines and survive $>3$ years after treatment. These encouraging clinical data raise a glimmer of hope in fighting glioblastoma after many years of intensive search for a cure.

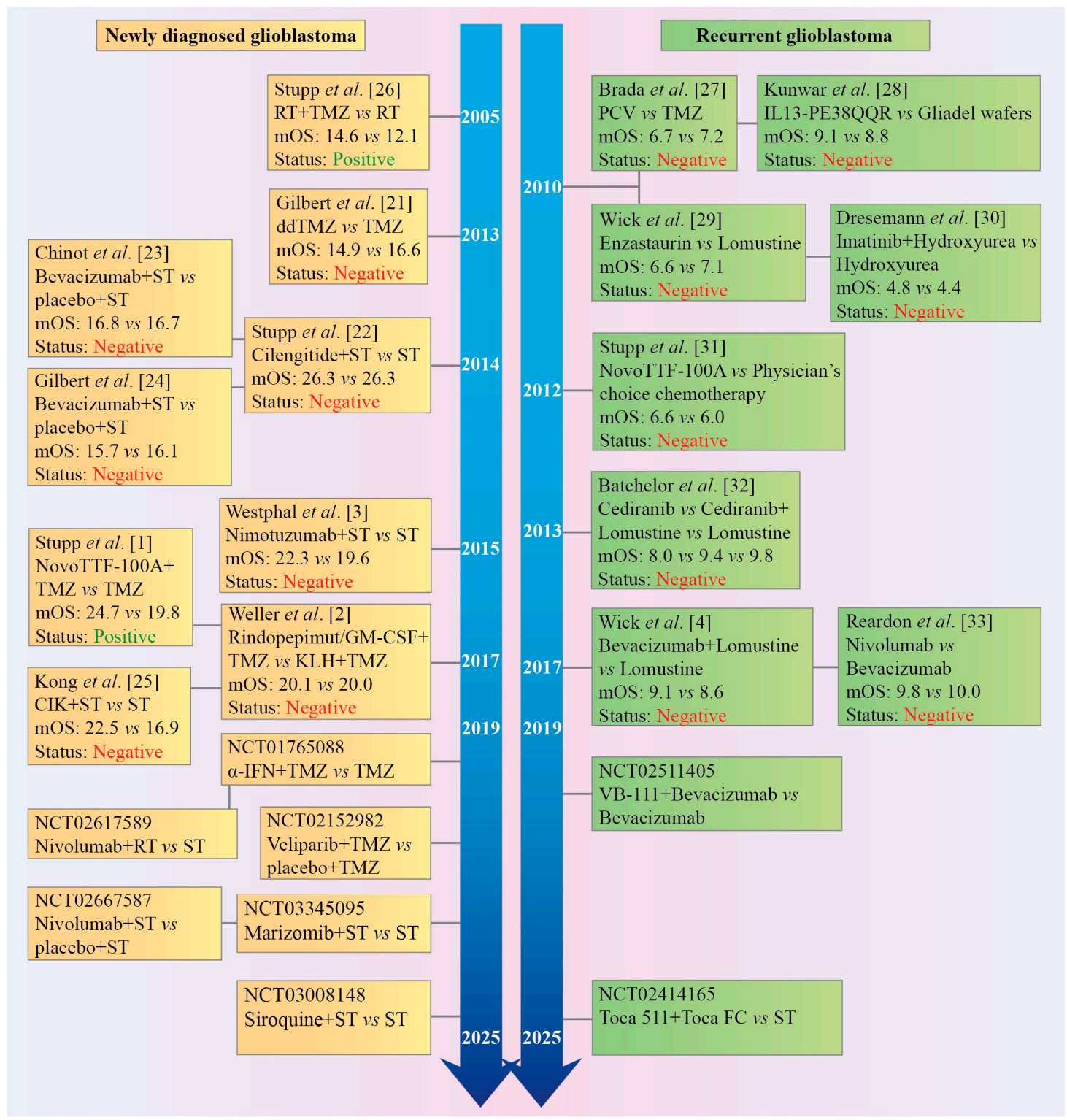

Figure 1. Timeline of phase III clinical trials in patients with newly diagnosed or recurrent glioblastoma. Almost all trials have been negative and failed to predict positive outcomes of the preceding phase II trials. $\alpha$-IFN: interferon-alpha; Bevacizumab: anti-vascular endothelial growth factor (VEGF) antibody; Cediranib: an inhibitor of VEGF receptor; CIK: autologous cytokine-induced killer cells; Enzastaurin: an inhibitor of protein kinase $\mathrm{C} \beta$ (PKC $\beta$, as well as $\mathrm{PKC} \alpha, \mathrm{PKC} \gamma$, and $\mathrm{PKC} \varepsilon$ at higher concentrations); 
IL13-PE38QQR, also known as Cintredekin besudotox: a recombinant chimeric cytotoxin composed of human interleukin 13 (IL-13) fused to a truncated, mutated form of Pseudomonas aeruginosa exotoxin A (PE38QQR); Marizomib: an irreversible proteasome inhibitor; mOS: median overall survival; Nimotuzumab: an anti-epidermal growth factor receptor (EGFR) antibody; Nivolumab: an anti-programmed cell death protein 1 (PD-1) antibody; NovoTTF-100A System ${ }^{\mathrm{TM}}$, or Optune ${ }^{\mathrm{TM}}$ generates Tumor Treating Fields (TTFields); PCV: procarbazine, lomustine, and vincristine; Rapamycin: an inhibitor of the mechanistic target of rapamycin (mTOR) protein kinase; RT: radiotherapy; Siroquine: sirolimus (rapamycin) plus hydroxychloroquine sulfate; ST: standard therapy; TMZ/ddTMZ: temozolomide/dose dense temozolomide; Toca 511: a gammaretroviral replicating vector encoding cytosine deaminase that converts the antifungal drug 5-fluorocytosine (FC) into the antineoplastic drug 5-fluorouracil (FU); VB-111: a non-replicating adenovirus 5 carrying a proapoptotic Fas-chimera transgene under the control of an endothelial cell-specific promoter; Veliparib: a poly(ADP-ribose) polymerase (PARP) 1 and 2 inhibitor. Cited literature: [1-4,21-33].

\section{Standard Therapy for Adult Glioblastoma: 15 Years of Experience and TTFields}

Since 2003, only two chemotherapeutic agents were approved as first-line drugs for the treatment of newly diagnosed glioblastoma: BCNU/carmustine (Gliadel ${ }^{\circledR}$ wafers intracranially implanted local chemotherapy composed of a biodegradable copolymer prolifeprospan 20 impregnated with the alkylating agent carmustine) in 2003 and the alkylating agent temozolomide/TMZ (Temodal ${ }^{\circledR}$, oral systemic chemotherapy) in 2005 [34,35]. However, the widespread use of Gliadel wafers was limited for different reasons including contradictory survival benefit and a high complication rate [35-39]. The current standard first-line treatment for adult patients ( $<65$ years of age) with newly diagnosed glioblastoma is maximum safe tumor resection, followed by concurrent radiotherapy (RT, 60 Gy delivered in 30 fractions, five times a week for 6 weeks, fractions of 2 Gy each) and daily oral TMZ (75 mg/m² per day, given 7 days per week), and then, after 4 treatment-free weeks, adjuvant TMZ up to 6 cycles (150-200 mg/m² per day, for five consecutive days, 28-day cycle) [40]. In a landmark phase III trial, this treatment regimen (the Stupp protocol) resulted in a median overall survival of 14.6 months in the RT-TMZ group $(n=287)$ versus 12.1 months in the RT only group $(n=286)$, 12.6 months versus 11.8 months in the MGMT-unmethylated subgroup, and 23.4 versus 15.3 months in the MGMT-methylated subgroup [40]. Since then, it has been established that, in addition to patient age and Karnofsky Performance Status, an extent of tumor resection is an independent prognostic factor for survival [41-43]; the use of anesthetic isoflurane, desflurane or a propofol infusion during glioblastoma surgery was not associated with overall survival [44]; irradiation doses above 60 Gy did not result in any survival prolongation regardless of exploited RT technique [45], and more than six cycles of TMZ also did not increase overall survival, including the MGMT-methylated subgroup [46-48], although no conclusive evidence exists [49], highlighting the need of a prospective randomized controlled trial to reconcile contradictory conclusions. A randomized, multicenter phase IIB trial of TMZ 12 cycles versus 6 cycles in patients with glioblastoma is ongoing (NCT02209948).

In addition to standard RT-TMZ, many patients routinely receive the standard corticosteroid dexamethasone to control peritumoral vasogenic cerebral edema and ameliorate neurological symptoms [50,51]. In clinical practice, steroids are administered more often to patients with aggressive tumor growth. Dexamethasone use (steroid dependency) was associated with shorter survival in primary and recurrent glioblastoma patients [52-62]. Corticosteroids are known to cause many adverse systemic effects, including immunosuppression and lymphopenia, which was also independently associated with shorter survival [63-69]. Thus, the negative association between dexamethasone use (steroid dependency) and survival may be due to more aggressive tumor growth in patients (such patients receive dexamethasone more likely), or due to dexamethasone-induced immunosuppression, or both, or due to another unknown reason. Since there are no randomized trials prospectively evaluating an association between dexamethasone use (its total daily dose, duration of application) and survival, no definitive answer can exist. 
Patients with glioblastoma also take anticonvulsants/anti-epileptic drugs (40-60\% of patients in different studies) to reduce tumor-associated seizures [70-72]. Levetiracetam is now the most frequently prescribed drug for brain tumor-related epilepsy, followed by valproic acid [70,71]. Although multiple retrospective clinical studies stated improved outcome of patients with newly diagnosed glioblastoma after the addition of valproic acid [73-81] or levetiracetam [82] to standard therapy, while others did not reveal a significant effect on overall survival $[70,75,83-87]$, the analysis of the prospective phase III clinical trials with a pooled cohort of 1869 patients demonstrated that levetiracetam or valproic acid did not influence median overall survival on multivariate analysis [88]. No significant impact on overall survival of patients with glioblastoma was also documented for other anti-epileptic drug [70].

Venous thromboembolism, including deep vein thrombosis and pulmonary embolism, is a common complication in patients with newly diagnosed glioblastoma, particularly in the first six months after diagnosis/during the course of treatment, associated with significant morbidity and shorter survival $[89,90]$. About $20-25 \%$ of patients require post-operative long-term curative treatment to manage symptomatic venous thromboembolism [91-93]. Low-molecular-weight heparin is preferred to other anticoagulants due to its excellent therapeutic index $[89,90,92]$. The application of low-molecular-weight heparin in glioblastoma patients did not affect overall survival in clinical trials [94].

Finally, prophylaxis against Pneumocystis jiroveci pneumonia is recommended for newly diagnosed glioblastoma patients receiving RT-TMZ, especially in combination with the chronic use of corticosteroids [95]. Interestingly, a retrospective analysis of 127 glioblastoma patients treated with standard therapy who did not receive prophylaxis against Pneumocystis jiroveci pneumonia revealed that only one patient suffered from pneumonia [96]. It was proposed to reconsider the administration of prophylactic drugs against pneumonia in every glioblastoma patient treated with RT-TMZ in favor of avoiding potentially unnecessary toxic prophylaxis [95].

Altogether, an extent of tumor resection, RT and TMZ are the main well-established modulators of patients' survival. In 2015, following a phase III trial (EF-14) [1], a new electric-physical cancer treatment modality (low-intensity, intermediate-frequency, alternating electric fields (TTFields) generated by the NovoTTF-100A device/Optune ${ }^{\circledR}$ ) was approved by the FDA for the treatment of newly diagnosed glioblastoma patients [97,98]. In this trial, patients (median age 56 years) were randomized 2:1 to the TTFields plus adjuvant TMZ group $(n=466)$ or the TMZ only group $(n=229)$. Median overall survival was 20.9 months in the TTFields-TMZ group versus 16.0 months in the TMZ only group from randomization (plus median time from diagnosis to randomization 3.8 months). In exploratory analyses, the percentage of patients alive at 2 years (from randomization) was $43 \%, 26 \%$ at 3 years, and $13 \%$ at 5 years in the TTFields-TMZ group versus $31 \%, 16 \%$, and $5 \%$, respectively, in the TMZ only group. No significant differences in the incidence, distribution, and severity of systemic adverse effects were observed between groups [1]. The meta-analysis data of primary and recurrent glioblastoma patients $(n=1769)$ also indicated that the addition of TTFields to standard therapy was associated with a better median overall survival after 1 and 2 years [99]. However, due to relatively small numbers of 3-year survivors, a 3-year survival rate could not be estimated reliably for TTFields-treated patients [99]. Integrating EF-14 trial data with glioblastoma epidemiology data, Guzauskas et al. estimated the conditional survival rates at 3, 5, 10, and 15 years for the EF-14 trial patients alive at year 2 [100]. The authors concluded that patients alive at year 2 after starting TTFields with adjuvant TMZ had $59.6 \%, 29.4 \%, 20.7 \%$, and $17.4 \%$ probability of surviving to year $3,5,10$, and 15 versus $53.1 \%, 14.7 \%, 10.3 \%$, and $8.7 \%$ probability of surviving for patients alive at year 2 after starting maintenance TMZ only [100]. These estimations of conditional survival should be confirmed by further monitoring survival of the EF-14 trial patients and in additional large randomized controlled TTFields trials with long follow-up. 


\section{Revision of the Landmark Stupp Trial as a Historical Control for Median Overall Survival in Non-Controlled Clinical Trials}

Over the last decade, the results of Stupp's EORTC/NCIC study [40] have been considered a historical control in non-controlled phase II trials assessing the efficacy of investigational drugs and for making phase III go/no-go decision. However, the follow-up phase III trials in adult patients with newly diagnosed glioblastoma demonstrated a trending increase in median overall survival in the control cohorts/arms receiving standard therapy (from $\approx 14$ to $\approx 20.0$ ) (Table 1 ). In addition, a Korean single-institution retrospective report on outcomes of 252 patients with newly diagnosed glioblastoma who received standard therapy between 2005 and 2013 indicated that median overall survival was 20.8 months [101]. It has been suggested that a general trend in increase of median overall survival (at least $>2-4$ months) is a result of more aggressive glioma management, improvement in surgery, RT, and toxicity management rather than a selection bias [3,45]. However, a trend of increasing median overall survival has not translated into an increase in the 3- or 5-year survival rates so far (Table 2). Importantly, an increase in median overall survival in the control cohorts/arms is one of the reasons why all positive non-controlled (compared with a historical control) phase II trials of investigational treatments in glioblastoma failed to predict positive phase III trials [2,102-105]. To the point, about 85\% of glioblastoma trials registered in ClinicalTrials.gov and conducted from 2005 to 2016 were non-controlled [106]. Altogether, the landmark Stupp's trial as a historical control for median overall survival in non-controlled trials should be revisited. The available data highlight the importance of designing controlled randomized phase II clinical trials due to the failure to an adequate estimate of therapeutic efficacy based on a historical control even after matching for patients eligibility [104,105].

Table 1. A trending increase in median overall survival in the control cohorts/arms receiving standard therapy in phase III clinical trials.

\begin{tabular}{|c|c|c|c|c|}
\hline Trial & $\begin{array}{l}\text { Number of } \\
\text { Patients in } \\
\text { the Control } \\
\text { Arm }\end{array}$ & $\begin{array}{c}\text { Median Overall Survival in the Landmark } \\
\text { Stupp Study and in the Control Standard } \\
\text { Therapy Arms/Cohorts of the Follow-Up } \\
\text { Phase III Trials }\end{array}$ & $\begin{array}{c}\text { Year of } \\
\text { Publication }\end{array}$ & References \\
\hline $\mathrm{TMZ}+\mathrm{RT}$ versus $\mathrm{RT}$ & 287 & $\begin{array}{l}14.6 \text { months; } 12.6 \text { months } \\
\text { (MGMT-unmethylated subgroup), } 23.4 \text { months } \\
\text { (MGMT-methylated subgroup) }\end{array}$ & 2009 & {$[40]$} \\
\hline $\begin{array}{c}\text { Dose-dense TMZ } \\
\text { versus standard TMZ }\end{array}$ & 411 & $\begin{array}{l}16.6 \text { months; } 14.6 \text { months } \\
\text { (MGMT-unmethylated subgroup); } 21.4 \text { months } \\
\text { (MGMT-methylated subgroup) }\end{array}$ & 2013 & [21] \\
\hline $\begin{array}{c}\text { Cilengitide }+ \text { ST versus } \\
\text { ST }\end{array}$ & 273 & 26.3 months (MGMT methylated cohort) & 2014 & [22] \\
\hline $\begin{array}{c}\text { Bevacizumab + ST } \\
\text { versus } \mathrm{ST}+\text { placebo }\end{array}$ & 463 & 16.7 months & 2014 & [23] \\
\hline $\begin{array}{c}\text { Bevacizumab + ST } \\
\text { versus ST + placebo }\end{array}$ & 317 & $\begin{array}{l}16.1 \text { months; in the pooled analysis of both } \\
\text { arms ( } n=621): 14.3 \text { months } \\
\text { (MGMT-unmethylated cohort); } 23.2 \text { months } \\
\text { (MGMT-methylated cohort) }\end{array}$ & 2014 & [24] \\
\hline $\begin{array}{l}\text { Nimotuzumab }+ \text { ST } \\
\text { versus ST }\end{array}$ & 71 & $\begin{array}{l}19.6 \text { months; } 15.5 \text { months } \\
\text { (MGMT-unmethylated subgroup); } 33.8 \text { months } \\
\text { (MGMT-methylated subgroup) }\end{array}$ & 2015 & [3] \\
\hline $\begin{array}{l}\text { Rindopepimut/GM-CSF } \\
+ \text { TMZ versus KLH + } \\
\text { TMZ }\end{array}$ & 374 & 20.0 months & 2017 & {$[2]$} \\
\hline $\begin{array}{c}\text { TTFields + TMZ versus } \\
\text { TMZ }\end{array}$ & 229 & $\begin{array}{l}19.8 \text { months ( } 16.0 \text { months from randomization } \\
\text { plus median time from diagnosis to } \\
\text { randomization } 3.8 \text { months) }\end{array}$ & 2017 & [1] \\
\hline
\end{tabular}


Table 2. The 2-, 3-, 5-, and 10-year overall survival (OS) rates for glioblastoma patients in clinical trials, registries and systematic reviews.

\begin{tabular}{|c|c|c|c|c|c|}
\hline Patient Groups/Registries & 2-Year OS Rate & 3-Year OS Rate & 5-Year OS Rate & $\begin{array}{l}\text { 10-Year } \\
\text { OS Rate }\end{array}$ & References \\
\hline $\begin{array}{l}\text { RT-TMZ group versus RT } \\
\text { only group }\end{array}$ & $27.2 \%$ vs. $10.9 \%$ & $16.0 \%$ vs. $4.4 \%$ & $9.8 \%$ vs. $1.9 \%$ & & \\
\hline & & & & & [40] \\
\hline $\begin{array}{l}\text { MGMT-unmethylated } \\
\text { subgroup }\end{array}$ & $14.8 \%$ vs. $1.8 \%$ & $11.1 \%$ vs. $0 \%$ & $8.3 \%$ vs. $0 \%$ & & \\
\hline $\begin{array}{l}\text { RT-TMZ group versus RT } \\
\text { only group in } \\
\text { MGMT-methylated } \\
\text { subgroup }\end{array}$ & $48.9 \%$ vs. $23.9 \%$ & $27.6 \%$ vs. $7.8 \%$ & $13.8 \%$ vs. $5.2 \%$ & & \\
\hline $\begin{array}{c}\text { RT-TMZ } \\
\text { MGMT-methylated group }\end{array}$ & $56 \%$ & & & & [22] \\
\hline $\begin{array}{l}\text { RT-TMZ group (exploratory } \\
\text { analysis) }\end{array}$ & $31 \%$ & $16 \%$ & $5 \%$ & & {$[1]$} \\
\hline $\begin{array}{l}\text { RT-TMZ plus placebo group } \\
\text { The National Cancer }\end{array}$ & $30.1 \%$ & & & & [23] \\
\hline $\begin{array}{l}\text { Institute's SEER Program } \\
(1985-2005, n=5991) \\
\text { The National Cancer }\end{array}$ & $9.5 \%$ & $5.4 \%$ & $3.6 \%$ & $2.9 \%$ & [107] \\
\hline $\begin{array}{c}\text { Institute's SEER Program } \\
(2005-2007)\end{array}$ & $24 \%$ & & & & [108] \\
\hline $\begin{array}{l}\text { The Central Brain Tumor } \\
\text { Registry of the United } \\
\text { States (CBTRUS) } \\
(1995-2011, n=30611)\end{array}$ & $14.8 \%$ & $8.7 \%$ & $5 \%$ & $2.6 \%$ & [109] \\
\hline Systematic reviews & & $2-5 \%$ & & $<1 \%$ & [110] \\
\hline
\end{tabular}

\section{No Molecularly Targeted Drug(s) for Glioblastoma on the Horizon}

About 190 phase II and 25 phase III glioblastoma clinical trials were launched between 2005 and 2015. In total, 100 different agents (43 clinically approved and 57 with investigational status: 67 small molecules, 32 biologicals, and one unclassified substance) were tested in those trials [111]. The systematic reviews and meta-analyses studies evaluating efficacy of the addition of molecularly targeted drugs to RT or standard therapy for newly diagnosed or recurrent glioblastoma showed no improvement in overall survival but increased risks of severe adverse events [112-115]. An overview of 100 ongoing Phase I/II glioma chemotherapy trials is given in [116]. Comparing ongoing trials with 29 phase I/II trials published in 2011, it was found that there is an increase in the number of trials using two drugs (from $24.1 \%$ to $44.9 \%$ ) and an increase in the number of drugs able to pass the blood-brain barrier (7.14\% versus $64.29 \%$ ) [116].

It is worth mentioning a currently ongoing individualized screening trial of innovative glioblastoma therapy (INSIGhT) designed as a randomized, multi-arm phase II trial for patients with newly diagnosed glioblastoma and unmethylated MGMT promoter (NCT02977780) [117]. In this trial, patients are assigned to experimental arms according to their specific genetic aberrations. INSIGhT compares experimental arms to standard therapy. Three experimental arms consist of neratinib (EGFR, HER2, and HER4 inhibitor), abemaciclib (CDK4 / 6 inhibitor) or CC-115 (TORC1/2 and DNA-PK inhibitor) added to radio- or radiochemotherapy [117]. In addition, a randomized controlled phase III trial in patients with recurrent glioblastoma comparing standard chemotherapy versus chemotherapy chosen by cancer stem cell chemosensitivity testing by the ChemoID drug response assay (NCT03632135) has been launched. However, the inspiring concept of personalized medicine based on a patient-specific combination of targeted drugs has been challenged recently [118-120]. In the preliminary proof-of-concept trials, efficacy of targeted therapy matched to genomic alterations has not been proved in advanced carcinomas [121,122]. Thus, targeted drugs matched to specific mutant kinases might also not result in any benefit in personalized precision medicine trials in glioblastoma patients. 
Glioblastoma is highly vascularized, critically dependent on angiogenesis brain neoplasm that provides a rationale for targeting a formation of blood vessels. However, in two phase III trials (RTOG 0825 and AVAglio), the addition of bevacizumab, a humanized monoclonal antibody targeting vascular endothelial growth factor (VEGF), to standard therapy for newly diagnosed glioblastoma failed to demonstrate improvement in overall survival $[23,24]$. Further, in a randomized phase II trial of hypofractionated RT (40 Gy in 15 fractions) with bevacizumab $(n=50)$ or without bevacizumab $(n=25)$ in elderly patients ( $\geq 65$ years) with newly diagnosed glioblastoma, overall survival in two arms was similar (12.1 versus 12.2 months, ARTE trial, NCT01443676) [123]. In general, a meta-analysis of fourteen randomized clinical trials demonstrated that seven tested drugs with antiangiogenic potential did not improve overall survival in glioblastoma patients, either as first or second-line treatment, and either as single agent or in combination with conventional chemotherapy [124].

Beyond its costly purpose for brain edema reduction, the role of bevacizumab as a therapeutic anti-tumor agent remains uncertain even for recurrent glioblastoma $[125,126]$. Bevacizumab was approved by the FDA for the treatment of recurrent glioblastoma relying upon the results of two non-controlled phase II trials without the completion of a controlled randomized phase III trial [127]. In contrast, the European Medicines Agency has not approved bevacizumab, since a phase III trial comparing lomustine plus bevacizumab versus lomustine in progressive glioblastoma revealed no significant difference between groups ( 9.1 versus 8.6 months, respectively) [4]. The systematic review and meta-analysis of randomized controlled studies combining bevacizumab with chemotherapy versus single-agent therapy in recurrent glioblastoma indicated no overall survival benefit from combination $[5,128]$. In a randomized controlled phase II trial ( $n=155$, TAVAREC trial), the addition of bevacizumab to TMZ in patients with first recurrence of grade II/III glioma without $1 \mathrm{p} / 19 \mathrm{q}$ co-deletion did not also improve overall survival [129]. In different randomized trials, patients with recurrent glioblastoma receiving bevacizumab alone had a median overall survival of about 7-10 months from recurrence, and this efficacy was comparable to lomustine monotherapy [5-7]. Moreover, in the retrospective studies, hypofractionated stereotactic re-irradiation therapy alone also demonstrated comparable survival benefit (a median survival time of about 9-11 months from recurrence) [130-133]. These observations are corroborated by data from a randomized phase II trial of APG101 (a CD95 ligand-binding fusion protein) plus reirradiation versus reirradiation only in progressive glioblastoma (a median overall survival of 11.5 months in each group) [134]. A recent retrospective study suggests that a combination of bevacizumab and re-irradiation (fractionated stereotactic RT) for progressive or recurrent high-grade gliomas may moderately increase median overall survival ( $>13$ months from recurrence) [135]. A randomized phase II trial of concurrent bevacizumab and re-irradiation versus bevacizumab only for recurrent glioblastoma patients is ongoing (NCT01730950). In addition, several trials including NovoTTF-100A with bevacizumab (NCT01894061) and NovoTTF-100A with bevacizumab and hypofractionated stereotactic irradiation (NCT01925573) for patients with recurrent glioblastoma have been launched. The results of a phase II study of pembrolizumab (anti-programmed cell death protein 1 antibody, PD-1) with and without bevacizumab for recurrent glioblastoma (NCT02337491) are awaited. Finally, a phase II non-randomized trial of pembrolizumab and reirradiation in bevacizumab-naïve and bevacizumab-resistant recurrent glioblastoma has been announced (NCT03661723). It should be noted that after tumor progression on bevacizumab, there is no effective therapeutic option, and an estimated median overall survival on bevacizumab progression and in post-bevacizumab salvage studies is 3.36 months and 4.46 months, respectively [7].

There are many ongoing clinical trials with immune checkpoint inhibitors in patients with primary and recurrent glioma/glioblastoma $[136,137]$. In a large randomized clinical trial for recurrent glioblastoma (CheckMate 143, NCT02017717), the anti-PD-1 antibody, nivolumab, did not demonstrate better efficacy in comparison to bevacizumab $[6,136]$. Two phase III trials comparing nivolumab versus TMZ, each in combination with RT, in patients with newly diagnosed MGMT-unmethylated glioblastoma (CheckMate-498, NCT02617589) and TMZ plus RT combined with nivolumab or placebo in patients with newly diagnosed MGMT-methylated glioblastoma (CheckMate-548, NCT02667587) 
are ongoing. There is emerging evidence that cancer patients with high tumor mutational load (a total number of nonsynonymous point mutations) or the total number of mutations per coding area and associated neoantigen burden show a much better response to immune checkpoint inhibitors. To evaluate the correlation between tumor mutational load and objective response rate, Yarchoan et al. plotted the objective response rate for PD-1 or anti-PD-L1 (PD ligand 1) therapy against median tumor mutational load across 27 tumor types/subtypes. The authors observed a strong correlation between them, with glioma/glioblastoma predicted to be among tumor types with the lowest chances to respond [138]. Although the tumor mutational load is correlated with response to immune checkpoint inhibitors, it is neither necessary nor sufficient to drive it [139-141]. In case studies, glioblastoma patients with DNA repair deficiency, which results in increased tumor mutational load, demonstrated significant clinical and immunological responses to immune checkpoint inhibition [142,143]. However, the analysis of the tumor mutational load, mismatch repair (MMR) and immune checkpoint expression in glioblastoma $(n=198)$ revealed that only 3.5\% of glioblastoma samples (seven of 198) had high tumor mutational load (DNA MMR mutations) associated with the loss of MLH1, MSH2, MSH6, and/or PMS2 expression [144]. Neither glioblastomas with high and moderate tumor mutational load nor IDH1 mutant gliomas exhibited increased PD-1+ T cell infiltrate or PD-L1 expression by tumor cells in comparison to samples with low tumor mutational load [144]. This analysis suggests that only some glioblastoma patients (mainly with DNA repair deficiency) might benefit from immune checkpoint inhibitors.

Altogether, an extremely high rate of failures in clinical trials and a lack of effective molecularly targeted drug(s) on the horizon have encouraged the development of conceptually distinct therapeutic approaches such as cellular immunotherapy and oncolytic virotherapy.

\section{Dendritic Cell/Peptide Vaccines and CAR T-cells for Glioblastoma Treatment: A Need for Large Controlled Trials to Prove Efficacy}

Systematic reviews and meta-analysis studies of phase I-II clinical trials demonstrated that the addition of dendritic cell vaccines to standard therapy improved the median overall survival and 2and 3-year survival rates of patients with newly diagnosed or recurrent high-grade gliomas [145-149]. Recent early phase clinical trials largely supported these conclusions (Table 3). However, until now, encouraging results derived from small controlled or non-controlled and/or non-randomized early phase clinical trials of vaccines have not been confirmed in multicenter, controlled, randomized phase II/III trials (Table 3). Only minor subgroups of patients benefit from dendritic cell/peptide vaccines. Recently, Liau et al. reported the interim results of a large randomized controlled phase III trial of DCVax-L vaccine for newly diagnosed glioblastoma (NCT00045968) [20]. Patients were randomized 2:1 to standard therapy plus DCVax-L $(n=232)$ or standard therapy plus placebo $(n=99)$. However, $86.4 \%$ of patients received dendritic cell vaccine at some point during the trial because of the cross-over study design. DCVax-L was administered by intra-dermal injection in the arm, six times in year one and twice per year thereafter. Among the patients $(n=223)$ who have lived $\geq 30$ months past their surgery, $67(30.0 \%)$ have a median overall survival of 46.5 months. Among the patients $(n=182)$ who have lived $\geq 36$ months past their surgery, $24.2 \%(n=44)$ have a median overall survival of 88.2 months. For patients with methylated MGMT $(n=131)$, median overall survival was 34.7 months from surgery, with a 3-year survival rate of $46.4 \%$ [20]. Altogether, these preliminary results seem very encouraging. However, the presentation of these interim immature data derived from a highly selected patient population as well as the trial design have been criticized [150]. The currently ongoing or recently announced phase II/III trials of dendritic cell/peptide vaccines are presented in Table 4. 
Table 3. Completed phase I-III clinical trials of vaccines for glioblastoma with primary outcomes.

\begin{tabular}{|c|c|c|c|c|c|}
\hline $\begin{array}{l}\text { Investigational Treatment } \\
\text { versus Comparator } \\
\text { Treatment }\end{array}$ & $\begin{array}{c}\mathrm{N} \text { of } \\
\text { Patients }\end{array}$ & $\begin{array}{l}\text { Newly } \\
\text { Diagnosed/ } \\
\text { Recurrent }\end{array}$ & $\begin{array}{l}\text { Results for Primary } \\
\text { Outcome }\end{array}$ & $\begin{array}{l}\text { ClinicalTrials. } \\
\text { gov Identifier }\end{array}$ & References \\
\hline \multicolumn{6}{|c|}{ Phase III trials } \\
\hline $\begin{array}{c}\text { Rindopepimut * plus GM-CSF } \\
\text { and TMZ versus KLH plus } \\
\text { TMZ }\end{array}$ & 745 & $\begin{array}{l}\text { Newly } \\
\text { diagnosed }\end{array}$ & $\begin{array}{c}\text { mOS: } 20.1 \text { versus } \\
20.0 \text { months (HR } 1.01,95 \% \\
\text { CI } 0.79-1.30 ; p=0.93 \text { ) } \\
\text { mOS: } 22.5 \text { versus }\end{array}$ & NCT01480479 & [2] \\
\hline $\begin{array}{l}\text { Autologous cytokine-induced } \\
\text { killer cells plus ST versus ST }\end{array}$ & 180 & $\begin{array}{l}\text { Newly } \\
\text { diagnosed }\end{array}$ & $\begin{array}{c}16.9 \text { months }(p=0.5237) \\
\text { mPFS: } 8.1 \text { versus } 5.4 \\
\text { months }(\text { HR } 0.693,90 \% \text { CI } \\
0.512-0.937, p=0.0218)\end{array}$ & NA & [25] \\
\hline $\begin{array}{l}\text { Autologous DC * vaccine } \\
\text { versus autologous PBMC }\end{array}$ & 331 & $\begin{array}{l}\text { Newly } \\
\text { diagnosed }\end{array}$ & Pending & NCT00045968 & [20] \\
\hline \multicolumn{6}{|c|}{ Phase II trials } \\
\hline $\begin{array}{l}\text { Rindopepimut plus GM-CSF } \\
\text { and standard or } \\
\text { dose-intensified TMZ versus a } \\
\text { historical control }\end{array}$ & 22 & $\begin{array}{l}\text { Newly } \\
\text { diagnosed }\end{array}$ & $\begin{array}{c}\text { mOS: } 23.6 \text { versus } \\
\text { 15.0 months }(\mathrm{HR}=0.23 ; 95 \% \\
\text { CI } 0.07-0.79 ; p=0.019) ; \\
\text { mPFS: } 15.2 \text { versus } \\
6.3 \text { months }(\mathrm{HR}=0.35,95 \% \\
\text { CI } 0.14-0.87 ; p=0.024)\end{array}$ & NCT00643097 & [151] \\
\hline $\begin{array}{l}\text { Rindopepimut plus GM-CSF } \\
\text { and adjuvant TMZ }\end{array}$ & 65 & $\begin{array}{l}\text { Newly } \\
\text { diagnosed }\end{array}$ & $\begin{array}{l}\text { mOS: } 21.8 \text { months; } \\
\text { mPFS: } 9.2 \text { months }\end{array}$ & NCT00458601 & [152] \\
\hline $\begin{array}{l}\text { Rindopepimut and GM-CSF } \\
\text { plus bevacizumab versus } \\
\text { KLH plus bevacizumab }\end{array}$ & 73 & Recurrent & $\begin{array}{c}\text { mOS: } 11.6 \text { versus } \\
9.3 \text { months }(\mathrm{HR}=0.57,95 \% \\
\text { CI } 0.33-0.98, p=0.039) \\
\text { mOS: } 18.3 \text { versus }\end{array}$ & NCT01498328 & [153] \\
\hline $\begin{array}{l}\text { ICT-107* versus unpulsed } \\
\text { autologous DC vaccine }\end{array}$ & 124 & $\begin{array}{c}\text { Newly } \\
\text { diagnosed }\end{array}$ & $\begin{array}{l}16.7 \text { months }(p>0.05) \\
\text { PFS: } 11.2 \text { versus } 9.0 \text { months } \\
(p=0.010)\end{array}$ & NCT01280552 & [154] \\
\hline $\begin{array}{l}\text { Autologous DC vaccine plus } \\
\text { ST versus ST }\end{array}$ & 76 & $\begin{array}{l}\text { Newly } \\
\text { diagnosed }\end{array}$ & $\begin{array}{c}\text { mOS: } 564 \text { versus } 568 \text { days } \\
(p=0.99) ; \\
\text { PFS: } 204 \text { versus } 210 \text { days } \\
(p=0.83) \\
\text { mOS: } 31.9 \text { versus }\end{array}$ & $\begin{array}{c}\text { EudraCT } \\
\text { number } \\
\text { 2009-015979-27 }\end{array}$ & [155] \\
\hline $\begin{array}{c}\text { Autologous DC vaccine plus } \\
\text { ST versus ST }\end{array}$ & 34 & $\begin{array}{l}\text { Newly } \\
\text { diagnosed }\end{array}$ & $\begin{array}{c}15.0 \text { months }(p<0.002) \\
\text { mPFS: } 8.5 \text { versus } \\
8.0 \text { months }(p=0.075)\end{array}$ & NA & [156] \\
\hline $\begin{array}{c}\text { Autologous DC vaccine plus } \\
\text { ST }\end{array}$ & 27 & $\begin{array}{l}\text { Newly } \\
\text { diagnosed } \\
\text { Newly }\end{array}$ & $\begin{array}{l}\text { mOS: } 23.4 \text { months; } \\
\text { mPFS: } 12.7 \text { months } \\
\text { mOS: } 13.7 \text { versus }\end{array}$ & NCT01006044 & [157] \\
\hline $\begin{array}{l}\text { Autologous DC vaccine plus } \\
\text { ST versus ST plus placebo }\end{array}$ & 43 & $\begin{array}{l}\text { diagnosed } \\
\text { or } \\
\text { recurrent }\end{array}$ & $\begin{array}{l}10.7 \text { months }(p=0.05) \\
\text { mPFS: } 7.7 \text { versus } \\
6.9 \text { months }(p=0.75)\end{array}$ & NA & [158] \\
\hline HSPPC-96 * plus TMZ & 46 & $\begin{array}{l}\text { Newly } \\
\text { diagnosed }\end{array}$ & $\begin{array}{l}\text { mOS: } 23.8 \text { months; } \\
\text { mPFS: } 18.0 \text { months }\end{array}$ & NCT00905060 & [17] \\
\hline $\begin{array}{c}\text { ERC1671 } \\
\text { */GM-CSF/cyclophosphamide } \\
\text { plus bevacizumab versus } \\
\text { placebo plus bevacizumab }\end{array}$ & 9 & Recurrent & $\begin{array}{l}\text { Interim mOS: } 12.0 \text { versus } \\
7.5 \text { months }\end{array}$ & NCT01903330 & [159] \\
\hline LAK cells * & 33 & $\begin{array}{c}\text { Newly } \\
\text { diagnosed }\end{array}$ & mOS: 20.5 months & NCT00331526 & [160] \\
\hline \multicolumn{6}{|c|}{ Phase I and I/II trials } \\
\hline $\begin{array}{l}\text { IMA950* vaccine with poly } \\
\text { ICLC plus ST }\end{array}$ & 16 & $\begin{array}{l}\text { Newly } \\
\text { diagnosed }\end{array}$ & mOS: 21.2 months & NCT01920191 & [161] \\
\hline $\begin{array}{c}\text { Autologous DC vaccine plus } \\
\text { ST }\end{array}$ & 23 & $\begin{array}{l}\text { Newly } \\
\text { diagnosed }\end{array}$ & mOS: 31.4 months & NA & [162] \\
\hline $\begin{array}{c}\text { Autologous DC vaccine plus } \\
\text { ST versus ST }\end{array}$ & 25 & $\begin{array}{l}\text { Newly } \\
\text { diagnosed }\end{array}$ & $\begin{array}{c}\text { mOS: } 17.0 \text { versus } \\
10.5 \text { months }(p<0.05)\end{array}$ & NA & [163] \\
\hline $\begin{array}{l}\text { Autologous DC vaccine plus } \\
\text { ST versus a historical control }\end{array}$ & 11 & $\begin{array}{l}\text { Newly } \\
\text { diagnosed }\end{array}$ & $\begin{array}{c}\text { mOS: } 759 \text { days versus } \\
585 \text { days } \\
\text { mOS: } 18.3 \text { months in }\end{array}$ & NCT00846456 & [164] \\
\hline $\begin{array}{c}\text { Autologous DC vaccine plus } \\
\text { ST }\end{array}$ & 77 & $\begin{array}{l}\text { Newly } \\
\text { diagnosed }\end{array}$ & $\begin{array}{l}\text { ITT analysis; } \\
\text { mPFS: } 10.4 \text { months in the } \\
\text { ITT group versus } 20.4 \\
\text { months in the PP group }\end{array}$ & NA & [165] \\
\hline
\end{tabular}


Table 3. Cont.

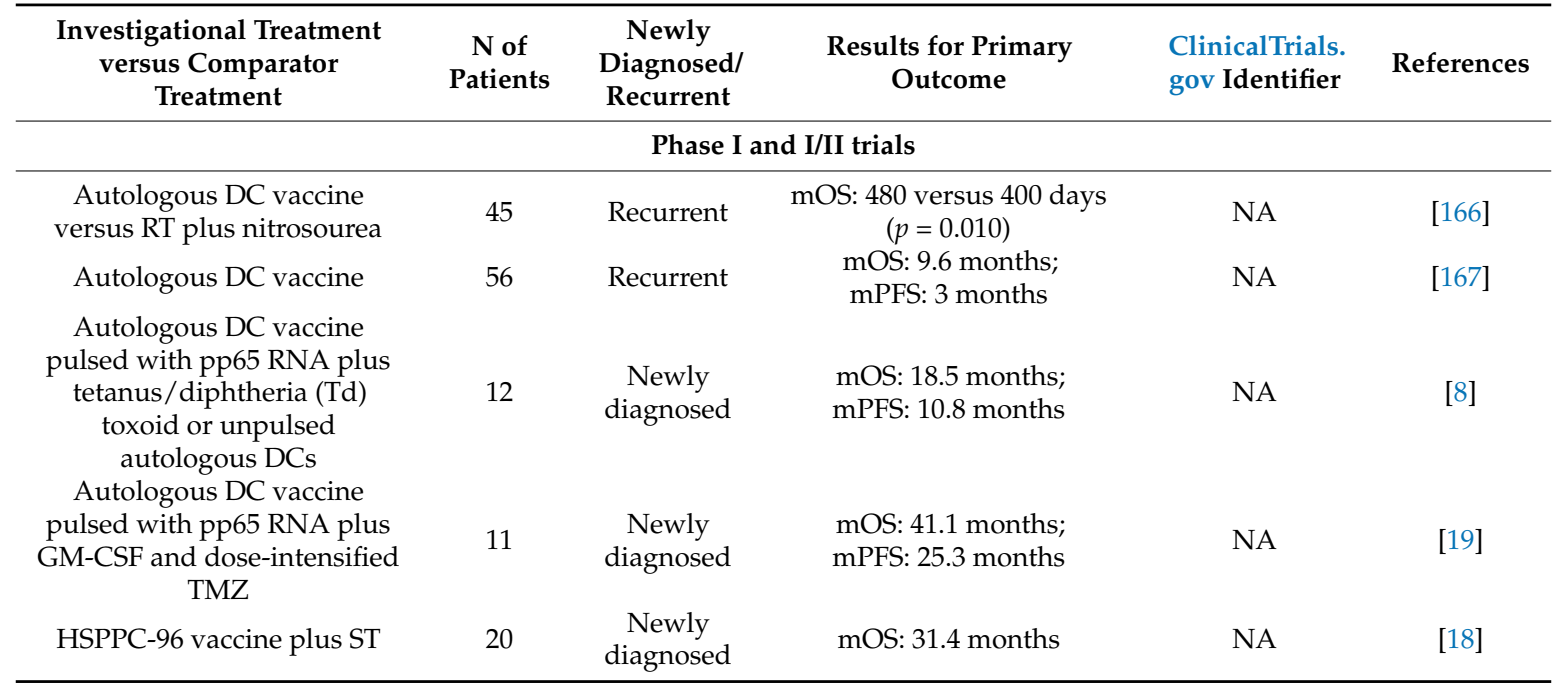

* DC: dendritic cells; ERC1671 vaccine is composed of primary irradiated/inactivated whole tumor cells and lysates from the patient to be treated and from three other allogeneic and autologous glioblastoma patients; GM-CSF: granulocyte-macrophage colony-stimulating factor; Rindopepimut, or CDX-110-KLH peptide vaccine, presents a 14-amino acid peptide corresponding to the fusion junction of EGFRvIII, which is linked to the keyhole limpet hemocyanin (KLH), a large copper-containing immunogenic carrier glycoprotein; HSPPC-96 peptide vaccine is comprised of autologous antigenic peptides chaperoned by heat shock glycoprotein-96; ICLC: an immunostimulating adjuvant consisting of double-stranded RNAs of polyinosinic-polycytidylic acid stabilized with poly L-lysine in carboxymethylcellulose; ICT-107 vaccine presents an autologous dendritic cell vaccine pulsed with peptides from six glioma-associated antigens (HER2, TRP-2, gp100, MAGE-1, IL13R $\alpha 2$, and AIM-2); IMA950 peptide vaccine consists of 11 glioma-associated peptides; ITT: intention-to-treat; LAK cells: lymphokine-activated killer cells; mOS: median overall survival; mPFS: median progression-free survival; PP: per protocol; ST: standard therapy; TMZ: temozolomide.

Table 4. Ongoing phase II/III clinical trials of dendritic cell/peptide vaccines in newly diagnosed or recurrent glioblastoma patients.

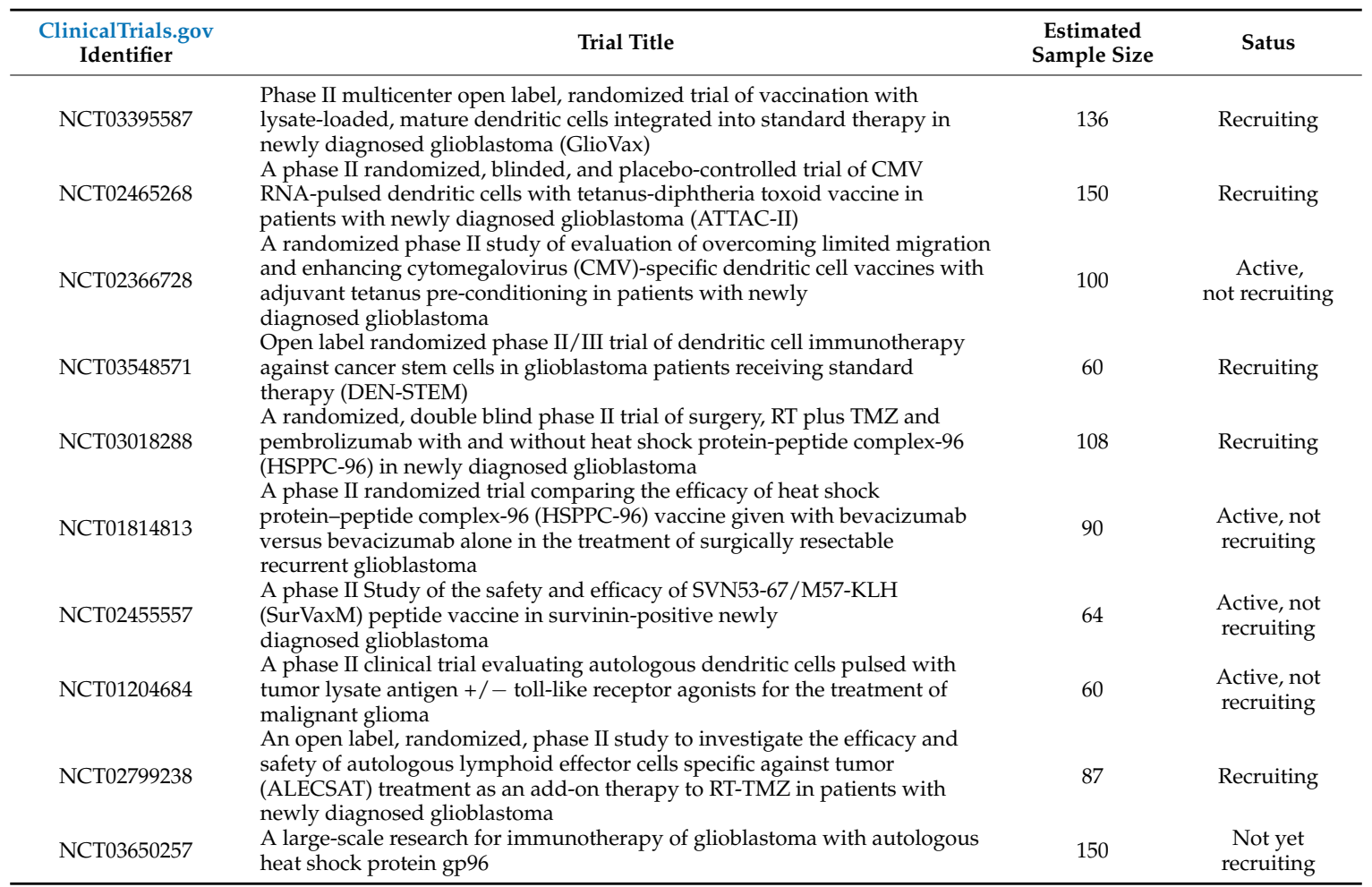


Genetically engineered chimeric antigen receptor-expressing T-cells (CAR T-cells) present recently advanced immunotherapy technology, which showed significant antiglioma activity in preclinical models. Initial experience with CAR T-cells targeting EGFRvIII, epidermal growth factor receptor 2 (HER2), and interleukin 13 receptor $\alpha 2$ (IL13R $\alpha 2$ ) has demonstrated their safety and antitumor activity in some glioblastoma patients [168-170]. However, it is too early to judge about the efficacy of CAR T-cell immune-therapeutics for which heterogeneous antigen expression and the immunosuppressive tumor microenvironment are considered the major barriers [171,172]. Glioblastoma antigens that are targeted by CAR T-cell therapy in ongoing clinical trials include EGFRvIII (NCT01454596, NCT02209376, NCT02844062, and NCT03283631), HER2 (NCT02442297, NCT01109095, and NCT03389230), IL-13R $\alpha 2$ (NCT02208362), ephrin type-A receptor 2 (EphA2) (NCT02575261), and programmed death-ligand 1 (PD-L1) (NCT02937844).

\section{Oncolytic Virotherapy for Glioma/Glioblastoma Treatment at Recurrence: Feasibility and Safety in Phase I Trials with Promising Efficacy in Subsets of Patients}

Different oncolytic viruses have been tested in progressive/recurrent glioblastoma/glioma and proved feasibility and safety, but not efficacy, in terms of median overall survival in randomized trials until now [173]. Here, we discuss the oncolytic viruses that have been recently advanced to phase I/II trials in recurrent glioma patients and demonstrated remarkable efficacy in subsets of patients.

DNX-2401 (Ad5-Delta-24-RGD; tasadenoturev) is an infectivity-enhanced, replication-competent, tumor-selective oncolytic adenovirus 5 (Ad5)-based vector [174]. In a phase I dose-escalation trial of DNX-2401 in 37 patients with recurrent malignant glioma [13], 25 patients received a single intratumoral injection (eight dose levels: $1 \times 10^{7}-3 \times 10^{10} \mathrm{vp}$ in $1 \mathrm{~mL}$ ) of DNX-2401 through the biopsy needle into recurrent tumor, while 12 patients underwent intratumoral injection $\left(1 \times 10^{7}-3 \times 10^{8} \mathrm{vp}\right)$ through a permanently implanted catheter to mark the injection site. Two weeks later, the tumor and catheter were resected. In a first cohort, $20 \%$ of patients survived $>3$ years from treatment and three patients showed $>3$ years of progression-free survival from treatment. The analysis of post-treatment surgical specimens from a second cohort revealed that DNX-2401 replicated and spread within the tumor and induced CD8+ and T-bet+ cells infiltration. However, some patients did not demonstrate evidence of infection and therapeutic response. No dose-limiting toxicities were observed and no maximum tolerated dose was identified in this trial [13]. In a randomized phase $\mathrm{Ib}$ trial of DNX-2401 versus DNX-2401 plus interferon gamma (IFN- $\gamma$ ) for recurrent glioblastoma (first or second recurrence, $n=27$; TARGET-I trial, NCT02197169), the 1- and 1.5-year overall survival rates for all patients enrolled (regardless of treatment assignment) was $33 \%$ and $22 \%$, respectively, and the addition of IFN- $\gamma$ did not improve survival upon a preliminary intent-to-treat analysis [175]. The combination of DNX-2401 delivered directly into the tumor with anti-PD-1 antibodies (pembrolizumab) administered intravenously is under evaluation in a phase II trial for recurrent glioblastoma/gliosarcoma (CAPTIVE/KEYNOTE-192, NCT02798406). Further, a phase I trial (NCT03330197) of intratumoral Ad-RTS-hIL-12, an inducible adenoviral vector engineered to express human interleukin 12 (hIL-12) in the presence of the activator ligand veledimex in pediatric patients with recurrent or progressive grade III/IV glioma $(n=25)$ demonstrated good tolerability of controlled local IL-12 expression [176]. A similar phase I trial in adults with glioblastoma/glioma is ongoing (NCT02026271).

The polio-rhinovirus chimera (PVSRIPO) targeting the poliovirus receptor CD155 represents a replication-competent attenuated poliovirus type 1 (Sabin) with its internal ribosome entry site substituted for that of human rhinovirus type 2. This internal ribosome entry site replacement ablates neurovirulence of PVSRIPO preventing from propagation in neurons. In a phase I trial (NCT01491893) with a dose-escalation phase (ranging between $10^{7}-10^{10} 50 \%$ tissue-culture infectious doses $\left(\mathrm{TCID}_{50}\right)$ and then a dose-expansion phase $\left(5.0 \times 10^{7} \mathrm{TCID}_{50}\right)$, a total of 61 recurrent supratentorial grade IV malignant glioma patients were treated with intratumoral infusion of PVSRIPO by convection-enhanced delivery via a catheter [14]. Sixty nine percent of the patients had grade 1 
or 2 PVSRIPO infusion-related adverse events. In the dose-expansion phase, 19\% of the patients had grade 3 or higher PVSRIPO-related adverse events. No neuropathogenicity or virus shedding was observed. Median overall survival among all 61 patients was 12.5 months. Overall survival reached a plateau at 24 months, with overall survival rate being $21 \%$ at 24 and 36 months. A few patients remained alive $>57-70$ months after the PVSRIPO infusion. It should be noted that some patients received additional treatments after the administration of PVSRIPO: 37 patients were treated with TMZ, lomustine, or other agents and 34 patients received bevacizumab to mitigate peritumoral inflammation [14]. A randomized phase II trial of PVSRIPO only or in combination with single-cycle lomustine in patients with recurrent grade IV malignant glioma (NCT02986178) is ongoing.

Oncolytic H-1 parvovirus (ParvOryx) whose natural host is the rat was tested in a phase I/IIa dose-escalating trial with different routes of administration in patients with recurrent glioblastoma [15]. Eighteen patients were enrolled. ParvOryx was administered via intratumoral or intravenous injection, then tumors were resected 9 days after treatment, and parvovirus was re-administered around the resection cavity. Median overall survival was 464 days ( $\approx 15.5$ months) after first ParvOryx treatment. Eight patients survived $>12$ months and three patients $>24$ months after first administration of ParvOryx. Clinical response did not depend on the dose or route of ParvOryx administration. A maximum tolerated dose was not identified. Tumors from six ParvOryx-treated patients displayed strong CD8+ and CD4+ T lymphocytes infiltration [15].

Toca 511 is a retroviral replication-competent vector based on murine leukemia virus encoding the yeast cytosine deaminase that converts the antifungal drug 5 -fluorocytosine into the antineoplastic drug 5-fluorouracil. In a phase I trial (NCT01470794) of Toca 511 injected into resection cavity of patients with recurrent high-grade gliomas $(n=56)$, followed by cycles of oral 5-fluorocytosine, 23 patients matched the recommended phase III Toca 511 dose [16]. In this patient subgroup (the phase III-eligible subgroup), which included both IDH1-mutant and wild type tumors, median overall survival was 14.4 months, the 1- and 2-year survival rates were $65.2 \%(15 / 23)$ and $34.8 \%(8 / 23)$. The estimated probability of a 3-year survival rate was $26.1 \%(6 / 23)$. Five patients demonstrated complete response and have been alive 33.9-52.2 months after Toca 511 administration [16]. A randomized phase II/III trial of Toca 511 combined with 5-fluorocytosine versus standard of care in patients undergoing planned resection for recurrent glioblastoma or anaplastic astrocytoma is ongoing (NCT02414165). Several other ongoing clinical trials in adult patients with recurrent glioblastoma/glioma include: a phase I/II trial of oncolytic vaccinia virus TG6002 combined with flucytosine (ONCOVIRAC, NCT03294486); a phase I trial of a measles virus derivative producing carcinoembryonic antigen (NCT00390299); a phase I trial of M032, a genetically engineered herpes simplex virus (HSV-1) expressing IL-12 (NCT02062827); and a phase I trial of a genetically engineered HSV-1, rQNestin34.5v.2, with cyclophosphamide (NCT03152318).

In general, early-phase clinical trials discussed above demonstrated that oncolytic virotherapy might markedly improve survival in subsets of patients. However, a pooled analysis of recent virotherapy trials for recurrent glioblastoma revealed that the 2- and 3-year survival rates were comparable to non-virotherapy clinical trials (2-year survival: 15\% versus 12\%; 3-year survival rate: $9 \%$ versus $6 \%$ ) [177]. Thus, a benefit of oncolytic virotherapy has yet to be proven in the large randomized controlled phase II/III trials.

\section{Is a Benefit Derived from Immunotherapy/Oncolytic Virotherapy Correlated with a Degree of Immunosuppression?}

Only subsets of patients benefit from vaccination/oncolytic virotherapy. In clinical trials, immunotherapies/oncolytic viruses are assessed concurrently with or after standard therapy. Importantly, arguing against its putative positive immunomodulatory role, standard therapy induces systemic immunosuppression and long-lasting severe lymphopenia [178-187], and may interfere with the immunotherapy/oncolytic virotherapy efficacy, which is critically dependent on the activity of the host's own immune cells $[10,159,188-197]$. In support of this, recent studies have reported that high 
blood CD3+/CD4+ T cells counts [159] and tumor-infiltrating lymphocyte density [188] were correlated with better overall survival in glioblastoma patients receiving dendritic cell vaccination, while adjuvant TMZ hampered a CD8+ T cell count increase and the generation of CD8+ T cell-associated antitumor memory promoted by dendritic cell vaccination [198]. Standard therapy differentially affects the immune system of each patient [198-200], and patients with less severe standard therapy-induced immune suppression might derive more benefit from immunotherapy/oncolytic virotherapy than severely immunosuppressed patients. Detailed blood/tumor immunophenotyping should be incorporated in immunotherapy / oncolytic virotherapy trials to correlate immune cell subsets (counts, phenotype), immune responses to therapy and survival of patients to find immune-related predictive/prognostic markers.

\section{Conclusions}

Since 2003, only two chemotherapeutic agents have been approved for the treatment of newly diagnosed glioblastoma: BCNU/carmustine and temozolomide. In 2015, tumor-treating alternating electric fields (TTFields) generated by the NovoTTF-100A device was approved by the FDA as a new glioblastoma treatment modality concurrently with standard therapy. However, more randomized controlled studies with long follow-up are required to assess the real clinical efficiency of the addition of TTFields to standard therapy in terms of overall survival and the 2-, 3- and 5-year survival rates. To date, no cytotoxic chemotherapeutic agent, antibody, molecularly targeted drug or combinations of small molecule inhibitors have been demonstrated to be more efficient than TMZ or to increase survival when combined with standard therapy. The addition of vaccines or oncolytic virotherapy to standard therapy has markedly improved the survival of subsets of patients in early-phase clinical trials. Large controlled trials are required to prove the efficacy of next-generation immunotherapeutics and oncolytic vectors. Since immunotherapy efficacy critically depends on the activity of the host's own immune cells, blood cell counts and immunophenotyping may potentially help find immune-related predictive/prognostic markers in immunotherapy/oncolytic virotherapy trials.

Funding: The work was financially supported by the Russian Foundation for Basic Research (RFBR), Grant No. 18-29-01009.

Conflicts of Interest: The authors declare no conflict of interest.

\section{References}

1. Stupp, R.; Taillibert, S.; Kanner, A.; Read, W.; Steinberg, D.; Lhermitte, B.; Toms, S.; Idbaih, A.; Ahluwalia, M.S.; Fink, K.; et al. Effect of Tumor-Treating Fields Plus Maintenance Temozolomide vs Maintenance Temozolomide Alone on Survival in Patients with Glioblastoma: A Randomized Clinical Trial. JAMA 2017, 318, 2306-2316. [CrossRef] [PubMed]

2. Weller, M.; Butowski, N.; Tran, D.D.; Recht, L.D.; Lim, M.; Hirte, H.; Ashby, L.; Mechtler, L.; Goldlust, S.A.; Iwamoto, F.; et al. Rindopepimut with temozolomide for patients with newly diagnosed, EGFRvIII-expressing glioblastoma (ACT IV): A randomised, double-blind, international phase 3 trial. Lancet Oncol. 2017, 18, 1373-1385. [CrossRef]

3. Westphal, M.; Heese, O.; Steinbach, J.P.; Schnell, O.; Schackert, G.; Mehdorn, M.; Schulz, D.; Simon, M.; Schlegel, U.; Senft, C.; et al. A randomised, open label phase III trial with nimotuzumab, an anti-epidermal growth factor receptor monoclonal antibody in the treatment of newly diagnosed adult glioblastoma. Eur. J. Cancer 2015, 51, 522-532. [CrossRef] [PubMed]

4. Wick, W.; Gorlia, T.; Bendszus, M.; Taphoorn, M.; Sahm, F.; Harting, I.; Brandes, A.A.; Taal, W.; Domont, J.; Idbaih, A.; et al. Lomustine and Bevacizumab in Progressive Glioblastoma. N. Engl. J. Med. 2017, 377, 1954-1963. [CrossRef] [PubMed]

5. Seystahl, K.; Wick, W.; Weller, M. Therapeutic options in recurrent glioblastoma-An update. Crit. Rev. Oncol. Hematol. 2016, 99, 389-408. [CrossRef] [PubMed] 
6. Reardon, D.A.; Omuro, A.; Brandes, A.A.; Rieger, J.; Wick, A.; Sepulveda, J.; Phuphanich, S.; de Souza, P.; Ahluwalia, M.S.; Lim, M.; et al. OS10.3 Randomized Phase 3 Study Evaluating the Efficacy and Safety of Nivolumab vs. Bevacizumab in Patients with Recurrent Glioblastoma: CheckMate 143. Neuro Oncol. 2017, 19, iii21. [CrossRef]

7. Tipping, M.; Eickhoff, J.; Ian Robins, H. Clinical outcomes in recurrent glioblastoma with bevacizumab therapy: An analysis of the literature. J. Clin. Neurosci. 2017, 44, 101-106. [CrossRef]

8. Mitchell, D.A.; Batich, K.A.; Gunn, M.D.; Huang, M.-N.; Sanchez-Perez, L.; Nair, S.K.; Congdon, K.L.; Reap, E.A.; Archer, G.E.; Desjardins, A.; et al. Tetanus toxoid and CCL3 improve dendritic cell vaccines in mice and glioblastoma patients. Nature 2015, 519, 366-369. [CrossRef]

9. Angelova, A.L.; Geletneky, K.; Nüesch, J.P.F.; Rommelaere, J. Tumor Selectivity of Oncolytic Parvoviruses: From in vitro and Animal Models to Cancer Patients. Front. Bioeng. Biotechnol. 2015, 3, 55. [CrossRef]

10. Garg, A.D.; Vandenberk, L.; Koks, C.; Verschuere, T.; Boon, L.; Van Gool, S.W.; Agostinis, P. Dendritic cell vaccines based on immunogenic cell death elicit danger signals and $\mathrm{T}$ cell-driven rejection of high-grade glioma. Sci. Transl. Med. 2016, 8, 328ra27. [CrossRef]

11. Stepanenko, A.A.; Chekhonin, V.P. A compendium of adenovirus genetic modifications for enhanced replication, oncolysis, and tumor immunosurveillance in cancer therapy. Gene 2018, 679, 11-18. [CrossRef] [PubMed]

12. Stepanenko, A.A.; Chekhonin, V.P. Tropism and transduction of oncolytic adenovirus 5 vectors in cancer therapy: Focus on fiber chimerism and mosaicism, hexon and pIX. Virus Res. 2018, 257, 40-51. [CrossRef] [PubMed]

13. Lang, F.F.; Conrad, C.; Gomez-Manzano, C.; Yung, W.K.A.; Sawaya, R.; Weinberg, J.S.; Prabhu, S.S.; Rao, G.; Fuller, G.N.; Aldape, K.D.; et al. Phase I Study of DNX-2401 (Delta-24-RGD) Oncolytic Adenovirus: Replication and Immunotherapeutic Effects in Recurrent Malignant Glioma. J. Clin. Oncol. 2018. [CrossRef] [PubMed]

14. Desjardins, A.; Gromeier, M.; Herndon, J.E.; Beaubier, N.; Bolognesi, D.P.; Friedman, A.H.; Friedman, H.S.; McSherry, F.; Muscat, A.M.; Nair, S.; et al. Recurrent Glioblastoma Treated with Recombinant Poliovirus. N. Engl. J. Med. 2018, 379, 150-161. [CrossRef] [PubMed]

15. Geletneky, K.; Hajda, J.; Angelova, A.L.; Leuchs, B.; Capper, D.; Bartsch, A.J.; Neumann, J.-O.; Schöning, T.; Hüsing, J.; Beelte, B.; et al. Oncolytic H-1 Parvovirus Shows Safety and Signs of Immunogenic Activity in a First Phase I/IIa Glioblastoma Trial. Mol. Ther. 2017, 25, 2620-2634. [CrossRef] [PubMed]

16. Cloughesy, T.F.; Landolfi, J.; Vogelbaum, M.A.; Ostertag, D.; Elder, J.B.; Bloomfield, S.; Carter, B.; Chen, C.C.; Kalkanis, S.N.; Kesari, S.; et al. Durable complete responses in some recurrent high-grade glioma patients treated with Toca 511 + Toca FC. Neuro Oncol. 2018, 20, 1383-1392. [CrossRef]

17. Bloch, O.; Lim, M.; Sughrue, M.E.; Komotar, R.J.; Abrahams, J.M.; O’Rourke, D.M.; D'Ambrosio, A.; Bruce, J.N.; Parsa, A.T. Autologous Heat Shock Protein Peptide Vaccination for Newly Diagnosed Glioblastoma: Impact of Peripheral PD-L1 Expression on Response to Therapy. Clin. Cancer Res. 2017, 23, 3575-3584. [CrossRef]

18. Ji, N.; Zhang, Y.; Liu, Y.; Xie, J.; Wang, Y.; Hao, S.; Gao, Z. Heat shock protein peptide complex-96 vaccination for newly diagnosed glioblastoma: A phase I, single-arm trial. JCI Insight 2018, 3. [CrossRef]

19. Batich, K.A.; Reap, E.A.; Archer, G.E.; Sanchez-Perez, L.; Nair, S.K.; Schmittling, R.J.; Norberg, P.; Xie, W.; Herndon, J.E.; Healy, P.; et al. Long-term Survival in Glioblastoma with Cytomegalovirus pp65-Targeted Vaccination. Clin. Cancer Res. 2017, 23, 1898-1909. [CrossRef]

20. Liau, L.M.; Ashkan, K.; Tran, D.D.; Campian, J.L.; Trusheim, J.E.; Cobbs, C.S.; Heth, J.A.; Salacz, M.; Taylor, S.; D'Andre, S.D.; et al. First results on survival from a large Phase 3 clinical trial of an autologous dendritic cell vaccine in newly diagnosed glioblastoma. J. Transl. Med. 2018, 16, 142. [CrossRef]

21. Gilbert, M.R.; Wang, M.; Aldape, K.D.; Stupp, R.; Hegi, M.E.; Jaeckle, K.A.; Armstrong, T.S.; Wefel, J.S.; Won, M.; Blumenthal, D.T.; et al. Dose-Dense Temozolomide for Newly Diagnosed Glioblastoma: A Randomized Phase III Clinical Trial. J. Clin. Oncol. 2013, 31, 4085-4091. [CrossRef] [PubMed]

22. Stupp, R.; Hegi, M.E.; Gorlia, T.; Erridge, S.C.; Perry, J.; Hong, Y.-K.; Aldape, K.D.; Lhermitte, B.; Pietsch, T.; Grujicic, D.; et al. Cilengitide combined with standard treatment for patients with newly diagnosed glioblastoma with methylated MGMT promoter (CENTRIC EORTC 26071-22072 study): A multicentre, randomised, open-label, phase 3 trial. Lancet Oncol. 2014, 15, 1100-1108. [CrossRef] 
23. Chinot, O.L.; Wick, W.; Mason, W.; Henriksson, R.; Saran, F.; Nishikawa, R.; Carpentier, A.F.; Hoang-Xuan, K.; Kavan, P.; Cernea, D.; et al. Bevacizumab plus Radiotherapy-Temozolomide for Newly Diagnosed Glioblastoma. N. Engl. J. Med. 2014, 370, 709-722. [CrossRef] [PubMed]

24. Gilbert, M.R.; Dignam, J.J.; Armstrong, T.S.; Wefel, J.S.; Blumenthal, D.T.; Vogelbaum, M.A.; Colman, H.; Chakravarti, A.; Pugh, S.; Won, M.; et al. A Randomized Trial of Bevacizumab for Newly Diagnosed Glioblastoma. N. Engl. J. Med. 2014, 370, 699-708. [CrossRef] [PubMed]

25. Kong, D.-S.; Nam, D.-H.; Kang, S.-H.; Lee, J.W.; Chang, J.-H.; Kim, J.-H.; Lim, Y.-J.; Koh, Y.-C.; Chung, Y.-G.; Kim, J.-M.; et al. Phase III randomized trial of autologous cytokine-induced killer cell immunotherapy for newly diagnosed glioblastoma in Korea. Oncotarget 2017, 8, 7003-7013. [CrossRef] [PubMed]

26. Stupp, R.; Mason, W.P.; van den Bent, M.J.; Weller, M.; Fisher, B.; Taphoorn, M.J.B.; Belanger, K.; Brandes, A.A.; Marosi, C.; Bogdahn, U.; et al. Radiotherapy plus Concomitant and Adjuvant Temozolomide for Glioblastoma. N. Engl. J. Med. 2005, 352, 987-996. [CrossRef] [PubMed]

27. Brada, M.; Stenning, S.; Gabe, R.; Thompson, L.C.; Levy, D.; Rampling, R.; Erridge, S.; Saran, F.; Gattamaneni, R.; Hopkins, K.; et al. Temozolomide Versus Procarbazine, Lomustine, and Vincristine in Recurrent High-Grade Glioma. J. Clin. Oncol. 2010, 28, 4601-4608. [CrossRef]

28. Kunwar, S.; Chang, S.; Westphal, M.; Vogelbaum, M.; Sampson, J.; Barnett, G.; Shaffrey, M.; Ram, Z.; Piepmeier, J.; Prados, M.; et al. Phase III randomized trial of CED of IL13-PE38QQR vs Gliadel wafers for recurrent glioblastoma. Neuro. Oncol. 2010, 12, 871-881. [CrossRef]

29. Wick, W.; Puduvalli, V.K.; Chamberlain, M.C.; van den Bent, M.J.; Carpentier, A.F.; Cher, L.M.; Mason, W.; Weller, M.; Hong, S.; Musib, L.; et al. Phase III study of enzastaurin compared with lomustine in the treatment of recurrent intracranial glioblastoma. J. Clin. Oncol. 2010, 28, 1168-1174. [CrossRef]

30. Dresemann, G.; Weller, M.; Rosenthal, M.A.; Wedding, U.; Wagner, W.; Engel, E.; Heinrich, B.; Mayer-Steinacker, R.; Karup-Hansen, A.; Fluge, Ø.; et al. Imatinib in combination with hydroxyurea versus hydroxyurea alone as oral therapy in patients with progressive pretreated glioblastoma resistant to standard dose temozolomide. J. Neurooncol. 2010, 96, 393-402. [CrossRef]

31. Stupp, R.; Wong, E.T.; Kanner, A.A.; Steinberg, D.; Engelhard, H.; Heidecke, V.; Kirson, E.D.; Taillibert, S.; Liebermann, F.; Dbalý, V.; et al. NovoTTF-100A versus physician's choice chemotherapy in recurrent glioblastoma: A randomised phase III trial of a novel treatment modality. Eur. J. Cancer 2012, 48, 2192-2202. [CrossRef] [PubMed]

32. Batchelor, T.T.; Mulholland, P.; Neyns, B.; Nabors, L.B.; Campone, M.; Wick, A.; Mason, W.; Mikkelsen, T.; Phuphanich, S.; Ashby, L.S.; et al. Phase III Randomized Trial Comparing the Efficacy of Cediranib As Monotherapy, and in Combination With Lomustine, Versus Lomustine Alone in Patients With Recurrent Glioblastoma. J. Clin. Oncol. 2013, 31, 3212-3218. [CrossRef] [PubMed]

33. Reardon, D.A.; Omuro, A.; Brandes, A.A.; Rieger, J.; Wick, A.; Sepulveda, J.; Phuphanich, S.; de Souza, P.; Ahluwalia, M.S.; Lim, M.; et al. OS10.3 Randomized Phase 3 Study Evaluating the Efficacy and Safety of Nivolumab vs Bevacizumab in Patients With Recurrent Glioblastoma: CheckMate 143. Neuro. Oncol. 2017, 19, iii21. [CrossRef]

34. Lillehei, K.O.; Kalkanis, S.N.; Liau, L.M.; Mydland, D.E.; Olson, J.; Paleologos, N.A.; Ryken, T.; Johnson, T.; Scullin, E. Rationale and design of the 500-patient, 3-year, and prospective Vigilant ObservatIon of GIIadeL WAfer ImplaNT registry. CNS Oncol. 2018, 7, CNS08. [CrossRef] [PubMed]

35. Ashby, L.S.; Smith, K.A.; Stea, B. Gliadel wafer implantation combined with standard radiotherapy and concurrent followed by adjuvant temozolomide for treatment of newly diagnosed high-grade glioma: A systematic literature review. World J. Surg. Oncol. 2016, 14, 225. [CrossRef] [PubMed]

36. Bregy, A.; Shah, A.H.; Diaz, M.V.; Pierce, H.E.; Ames, P.L.; Diaz, D.; Komotar, R.J. The role of Gliadel wafers in the treatment of high-grade gliomas. Expert Rev. Anticancer Ther. 2013, 13, 1453-1461. [CrossRef] [PubMed]

37. Chowdhary, S.A.; Ryken, T.; Newton, H.B. Survival outcomes and safety of carmustine wafers in the treatment of high-grade gliomas: A meta-analysis. J. Neurooncol. 2015, 122, 367-382. [CrossRef]

38. Nagpal, S. The Role of BCNU Polymer Wafers (Gliadel) in the Treatment of Malignant Glioma. Neurosurg. Clin. 2012, 23, 289-295. [CrossRef]

39. Xing, W.; Shao, C.; Qi, Z.; Yang, C.; Wang, Z. The role of Gliadel wafers in the treatment of newly diagnosed GBM: A meta-analysis. Drug Des. Dev. Ther. 2015, 9, 3341-3348. [CrossRef] 
40. Stupp, R.; Hegi, M.E.; Mason, W.P.; van den Bent, M.J.; Taphoorn, M.J.B.; Janzer, R.C.; Ludwin, S.K.; Allgeier, A.; Fisher, B.; Belanger, K.; et al. Effects of radiotherapy with concomitant and adjuvant temozolomide versus radiotherapy alone on survival in glioblastoma in a randomised phase III study: 5-year analysis of the EORTC-NCIC trial. Lancet Oncol. 2009, 10, 459-466. [CrossRef]

41. Brown, T.J.; Brennan, M.C.; Li, M.; Church, E.W.; Brandmeir, N.J.; Rakszawski, K.L.; Patel, A.S.; Rizk, E.B.; Suki, D.; Sawaya, R.; et al. Association of the Extent of Resection with Survival in Glioblastoma: A Systematic Review and Meta-analysis. JAMA Oncol. 2016, 2, 1460-1469. [CrossRef] [PubMed]

42. Almenawer, S.A.; Badhiwala, J.H.; Alhazzani, W.; Greenspoon, J.; Farrokhyar, F.; Yarascavitch, B.; Algird, A.; Kachur, E.; Cenic, A.; Sharieff, W.; et al. Biopsy versus partial versus gross total resection in older patients with high-grade glioma: A systematic review and meta-analysis. Neuro Oncol. 2015, 17, 868-881. [CrossRef] [PubMed]

43. Xia, L.; Fang, C.; Chen, G.; Sun, C. Relationship between the extent of resection and the survival of patients with low-grade gliomas: A systematic review and meta-analysis. BMC Cancer 2018, 18, 48. [CrossRef] [PubMed]

44. Cata, J.P.; Hagan, K.B.; Bhavsar, S.D.O.; Arunkumar, R.; Grasu, R.; Dang, A.; Carlson, R.; Arnold, B.; Potylchansky, Y.; Lipski, I.; et al. The use of isoflurane and desflurane as inhalational agents for glioblastoma surgery. A survival analysis. J. Clin. Neurosci. 2017, 35, 82-87. [CrossRef] [PubMed]

45. Kazda, T.; Dziacky, A.; Burkon, P.; Pospisil, P.; Slavik, M.; Rehak, Z.; Jancalek, R.; Slampa, P.; Slaby, O.; Lakomy, R. Radiotherapy of glioblastoma 15 years after the landmark Stupp's trial: More controversies than standards? Radiol. Oncol. 2018, 52, 121-128. [CrossRef]

46. Skardelly, M.; Dangel, E.; Gohde, J.; Noell, S.; Behling, F.; Lepski, G.; Borchers, C.; Koch, M.; Schittenhelm, J.; Bisdas, S.; et al. Prolonged Temozolomide Maintenance Therapy in Newly Diagnosed Glioblastoma. Oncologist 2017, 22, 570-575. [CrossRef]

47. Blumenthal, D.T.; Gorlia, T.; Gilbert, M.R.; Kim, M.M.; Burt Nabors, L.; Mason, W.P.; Hegi, M.E.; Zhang, P.; Golfinopoulos, V.; Perry, J.R.; et al. Is more better? The impact of extended adjuvant temozolomide in newly diagnosed glioblastoma: A secondary analysis of EORTC and NRG Oncology/RTOG. Neuro Oncol. 2017, 19, 1119-1126. [CrossRef]

48. Gramatzki, D.; Kickingereder, P.; Hentschel, B.; Felsberg, J.; Herrlinger, U.; Schackert, G.; Tonn, J.-C.; Westphal, M.; Sabel, M.; Schlegel, U.; et al. Limited role for extended maintenance temozolomide for newly diagnosed glioblastoma. Neurology 2017, 88, 1422-1430. [CrossRef]

49. Xu, W.; Li, T.; Gao, L.; Zheng, J.; Shao, A.; Zhang, J. Efficacy and safety of long-term therapy for high-grade glioma with temozolomide: A meta-analysis. Oncotarget 2017, 8, 51758-51765. [CrossRef]

50. Deutsch, M.B.; Panageas, K.S.; Lassman, A.B.; DeAngelis, L.M. Steroid management in newly diagnosed glioblastoma. J. Neurooncol. 2013, 113, 111-116. [CrossRef]

51. Ly, K.I.; Wen, P.Y. Clinical Relevance of Steroid Use in Neuro-Oncology. Curr. Neurol. Neurosci. Rep. 2017, 17, 5. [CrossRef] [PubMed]

52. Hohwieler Schloss, M.; Freidberg, S.R.; Heatley, G.J.; Lo, T.C. Glucocorticoid dependency as a prognostic factor in radiotherapy for cerebral gliomas. Acta Oncol. 1989, 28, 51-55. [CrossRef] [PubMed]

53. Watne, K.; Hannisdal, E.; Nome, O.; Hager, B.; Hirschberg, H. Prognostic factors in malignant gliomas with special reference to intra-arterial chemotherapy. Acta Oncol. 1993, 32, 307-310. [CrossRef]

54. Tieu, M.T.; Lovblom, L.E.; McNamara, M.G.; Mason, W.; Laperriere, N.; Millar, B.-A.; Ménard, C.; Kiehl, T.-R.; Perkins, B.A.; Chung, C. Impact of glycemia on survival of glioblastoma patients treated with radiation and temozolomide. J. Neurooncol. 2015, 124, 119-126. [CrossRef] [PubMed]

55. Michaelsen, S.R.; Christensen, I.J.; Grunnet, K.; Stockhausen, M.-T.; Broholm, H.; Kosteljanetz, M.; Poulsen, H.S. Clinical variables serve as prognostic factors in a model for survival from glioblastoma multiforme: An observational study of a cohort of consecutive non-selected patients from a single institution. BMC Cancer 2013, 13, 402. [CrossRef] [PubMed]

56. Shields, L.B.E.; Shelton, B.J.; Shearer, A.J.; Chen, L.; Sun, D.A.; Parsons, S.; Bourne, T.D.; LaRocca, R.; Spalding, A.C. Dexamethasone administration during definitive radiation and temozolomide renders a poor prognosis in a retrospective analysis of newly diagnosed glioblastoma patients. Radiat. Oncol. 2015, 10, 222. [CrossRef] [PubMed] 
57. Kostopoulou, O.N.; Mohammad, A.-A.; Bartek, J.; Winter, J.; Jung, M.; Stragliotto, G.; Söderberg-Nauclér, C.; Landázuri, N. Glucocorticoids promote a glioma stem cell-like phenotype and resistance to chemotherapy in human glioblastoma primary cells: Biological and prognostic significance. Int. J. Cancer 2017. [CrossRef] [PubMed]

58. Díez Valle, R.; Becerra Castro, V.; Marigil Sánchez, M.; Gállego Pérez-Larraya, J.; Núñez-Córdoba, J.M.; Tejada Solis, S. Results of a Policy of Fast Tapering of Steroids After Resection Surgery in Glioblastoma. World Neurosurg. 2018, 109, e845-e852. [CrossRef]

59. Pitter, K.L.; Tamagno, I.; Alikhanyan, K.; Hosni-Ahmed, A.; Pattwell, S.S.; Donnola, S.; Dai, C.; Ozawa, T.; Chang, M.; Chan, T.A.; et al. Corticosteroids compromise survival in glioblastoma. Brain 2016, 139, 1458-1471. [CrossRef]

60. Van Linde, M.E.; Brahm, C.G.; de Witt Hamer, P.C.; Reijneveld, J.C.; Bruynzeel, A.M.E.; Vandertop, W.P.; van de Ven, P.M.; Wagemakers, M.; van der Weide, H.L.; Enting, R.H.; et al. Treatment outcome of patients with recurrent glioblastoma multiforme: A retrospective multicenter analysis. J. Neurooncol. 2017. [CrossRef]

61. Duerinck, J.; Du Four, S.; Bouttens, F.; Andre, C.; Verschaeve, V.; Van Fraeyenhove, F.; Chaskis, C.; D'Haene, N.; Le Mercier, M.; Rogiers, A.; et al. Randomized phase II trial comparing axitinib with the combination of axitinib and lomustine in patients with recurrent glioblastoma. J. Neurooncol. 2017. [CrossRef] [PubMed]

62. Wong, E.T.; Lok, E.; Gautam, S.; Swanson, K.D. Dexamethasone exerts profound immunologic interference on treatment efficacy for recurrent glioblastoma. Br. J. Cancer 2015, 113, 232-241. [CrossRef] [PubMed]

63. Coutinho, A.E.; Chapman, K.E. The anti-inflammatory and immunosuppressive effects of glucocorticoids, recent developments and mechanistic insights. Mol. Cell. Endocrinol. 2011, 335, 2-13. [CrossRef] [PubMed]

64. Zen, M.; Canova, M.; Campana, C.; Bettio, S.; Nalotto, L.; Rampudda, M.; Ramonda, R.; Iaccarino, L.; Doria, A. The kaleidoscope of glucorticoid effects on immune system. Autoimmun. Rev. 2011, 10, 305-310. [CrossRef] [PubMed]

65. Cain, D.W.; Cidlowski, J.A. Immune regulation by glucocorticoids. Nat. Rev. Immunol. 2017, 17, $233-247$. [CrossRef] [PubMed]

66. Sengupta, S.; Thaci, B.; Crawford, A.C.; Sampath, P. Interleukin-13 Receptor Alpha 2-Targeted Glioblastoma Immunotherapy. Biomed. Res. Int. 2014, 2014, 1-8. [CrossRef] [PubMed]

67. Gustafson, M.P.; Lin, Y.; New, K.C.; Bulur, P.A.; O’Neill, B.P.; Gastineau, D.A.; Dietz, A.B. Systemic immune suppression in glioblastoma: The interplay between CD14+HLA-DRlo/neg monocytes, tumor factors, and dexamethasone. Neuro Oncol. 2010, 12, 631-644. [CrossRef] [PubMed]

68. Chitadze, G.; Flüh, C.; Quabius, E.S.; Freitag-Wolf, S.; Peters, C.; Lettau, M.; Bhat, J.; Wesch, D.; Oberg, H.-H.; Luecke, S.; et al. In-depth immunophenotyping of patients with glioblastoma multiforme: Impact of steroid treatment. Oncoimmunology 2017, 6, e1358839. [CrossRef] [PubMed]

69. Cook, A.M.; McDonnell, A.M.; Lake, R.A.; Nowak, A.K. Dexamethasone co-medication in cancer patients undergoing chemotherapy causes substantial immunomodulatory effects with implications for chemo-immunotherapy strategies. Oncoimmunology 2016, 5, e1066062. [CrossRef] [PubMed]

70. Knudsen-Baas, K.M.; Engeland, A.; Gilhus, N.E.; Storstein, A.M.; Owe, J.F. Does the choice of antiepileptic drug affect survival in glioblastoma patients? J. Neurooncol. 2016, 129, 461-469. [CrossRef]

71. Vecht, C.J.; Kerkhof, M.; Duran-Pena, A. Seizure Prognosis in Brain Tumors: New Insights and Evidence-Based Management. Oncologist 2014, 19, 751-759. [CrossRef] [PubMed]

72. Bruna, J.; Miró, J.; Velasco, R. Epilepsy in glioblastoma patients: Basic mechanisms and current problems in treatment. Expert Rev. Clin. Pharmacol. 2013, 6, 333-344. [CrossRef] [PubMed]

73. Guthrie, G.D.; Eljamel, S. Impact of particular antiepileptic drugs on the survival of patients with glioblastoma multiforme. J. Neurosurg. 2013, 118, 859-865. [CrossRef] [PubMed]

74. Watanabe, S.; Kuwabara, Y.; Suehiro, S.; Yamashita, D.; Tanaka, M.; Tanaka, A.; Ohue, S.; Araki, H. Valproic acid reduces hair loss and improves survival in patients receiving temozolomide-based radiation therapy for high-grade glioma. Eur. J. Clin. Pharmacol. 2017, 73, 357-363. [CrossRef] [PubMed]

75. Tsai, H.-C.; Wei, K.-C.; Tsai, C.-N.; Huang, Y.-C.; Chen, P.-Y.; Chen, S.-M.; Lu, Y.-J.; Lee, S.-T. Effect of valproic acid on the outcome of glioblastoma multiforme. Br. J. Neurosurg. 2012, 26, 347-354. [CrossRef] [PubMed]

76. Kerkhof, M.; Dielemans, J.C.M.; van Breemen, M.S.; Zwinkels, H.; Walchenbach, R.; Taphoorn, M.J.; Vecht, C.J. Effect of valproic acid on seizure control and on survival in patients with glioblastoma multiforme. Neuro Oncol. 2013, 15, 961-967. [CrossRef] 
77. Barker, C.A.; Bishop, A.J.; Chang, M.; Beal, K.; Chan, T.A. Valproic Acid Use During Radiation Therapy for Glioblastoma Associated With Improved Survival. Int. J. Radiat. Oncol. 2013, 86, 504-509. [CrossRef]

78. Rudà, R.; Pellerino, A.; Soffietti, R. Does valproic acid affect tumor growth and improve survival in glioblastomas? CNS Oncol. 2016, 5, 51-53. [CrossRef]

79. Weller, M.; Gorlia, T.; Cairncross, J.G.; van den Bent, M.J.; Mason, W.; Belanger, K.; Brandes, A.A.; Bogdahn, U.; Macdonald, D.R.; Forsyth, P.; et al. Prolonged survival with valproic acid use in the EORTC/NCIC temozolomide trial for glioblastoma. Neurology 2011, 77, 1156-1164. [CrossRef]

80. Redjal, N.; Reinshagen, C.; Le, A.; Walcott, B.P.; McDonnell, E.; Dietrich, J.; Nahed, B.V. Valproic acid, compared to other antiepileptic drugs, is associated with improved overall and progression-free survival in glioblastoma but worse outcome in grade II/III gliomas treated with temozolomide. J. Neurooncol. 2016, 127, 505-514. [CrossRef]

81. Yuan, Y.; Xiang, W.; Qing, M.; Yanhui, L.; Jiewen, L.; Yunhe, M. Survival analysis for valproic acid use in adult glioblastoma multiforme: A meta-analysis of individual patient data and a systematic review. Seizure 2014, 23, 830-835. [CrossRef] [PubMed]

82. Kim, Y.-H.; Kim, T.; Joo, J.-D.; Han, J.H.; Kim, Y.J.; Kim, I.A.; Yun, C.-H.; Kim, C.-Y. Survival benefit of levetiracetam in patients treated with concomitant chemoradiotherapy and adjuvant chemotherapy with temozolomide for glioblastoma multiforme. Cancer 2015, 121, 2926-2932. [CrossRef] [PubMed]

83. Valiyaveettil, D.; Malik, M.; Joseph, D.; Ahmed, S.; Kothwal, S.; Vijayasaradhi, M. Effect of valproic acid on survival in glioblastoma: A prospective single-arm study. South Asian J. Cancer 2018, 7, 159. [CrossRef] [PubMed]

84. Felix, F.H.C.; de Araujo, O.L.; da Trindade, K.M.; Trompieri, N.M.; Fontenele, J.B. Survival of children with malignant brain tumors receiving valproate: A retrospective study. Childs. Nerv. Syst. 2013, 29, 195-197. [CrossRef] [PubMed]

85. Breemen, M.S.M.; Rijsman, R.M.; Taphoorn, M.J.B.; Walchenbach, R.; Zwinkels, H.; Vecht, C.J. Efficacy of anti-epileptic drugs in patients with gliomas and seizures. J. Neurol. 2009, 256, 1519-1526. [CrossRef] [PubMed]

86. Berendsen, S.; Varkila, M.; Kroonen, J.; Seute, T.; Snijders, T.J.; Kauw, F.; Spliet, W.G.M.; Willems, M.; Poulet, C.; Broekman, M.L.; et al. Prognostic relevance of epilepsy at presentation in glioblastoma patients. Neuro Oncol. 2016, 18, 700-706. [CrossRef] [PubMed]

87. Toledo, M.; Sarria-Estrada, S.; Quintana, M.; Maldonado, X.; Martinez-Ricarte, F.; Rodon, J.; Auger, C.; Salas-Puig, J.; Santamarina, E.; Martinez-Saez, E. Prognostic implications of epilepsy in glioblastomas. Clin. Neurol. Neurosurg. 2015, 139, 166-171. [CrossRef]

88. Happold, C.; Gorlia, T.; Chinot, O.; Gilbert, M.R.; Nabors, L.B.; Wick, W.; Pugh, S.L.; Hegi, M.; Cloughesy, T.; Roth, P.; et al. Does Valproic Acid or Levetiracetam Improve Survival in Glioblastoma? A Pooled Analysis of Prospective Clinical Trials in Newly Diagnosed Glioblastoma. J. Clin. Oncol. 2016, 34, 731-739. [CrossRef]

89. Cote, D.J.; Smith, T.R. Venous thromboembolism in brain tumor patients. J. Clin. Neurosci. 2016, 25, 13-18. [CrossRef]

90. Morgan, E.R.; Mason, W.P.; Maurice, C. A critical balance: Managing coagulation in patients with glioma. Expert Rev. Neurother. 2016, 16, 803-814. [CrossRef]

91. Streiff, M.B.; Ye, X.; Kickler, T.S.; Desideri, S.; Jani, J.; Fisher, J.; Grossman, S.A. A prospective multicenter study of venous thromboembolism in patients with newly-diagnosed high-grade glioma: Hazard rate and risk factors. J. Neurooncol. 2015, 124, 299-305. [CrossRef] [PubMed]

92. Taillibert, S.; Taillandier, L.; Le Rhun, E. Venous thrombosis in patients with high-grade glioma. Curr. Opin. Oncol. 2015, 27, 516-521. [CrossRef] [PubMed]

93. Edwin, N.C.; Khoury, M.N.; Sohal, D.; McCrae, K.R.; Ahluwalia, M.S.; Khorana, A.A. Recurrent venous thromboembolism in glioblastoma. Thromb. Res. 2016, 137, 184-188. [CrossRef] [PubMed]

94. Schnoor, R.; Maas, S.L.N.; Broekman, M.L.D. Heparin in malignant glioma: Review of preclinical studies and clinical results. J. Neurooncol. 2015, 124, 151-156. [CrossRef] [PubMed]

95. De Vos, F.Y.; Gijtenbeek, J.M.; Bleeker-Rovers, C.P.; van Herpen, C.M. Pneumocystis jirovecii pneumonia prophylaxis during temozolomide treatment for high-grade gliomas. Crit. Rev. Oncol. Hematol. 2013, 85, 373-382. [CrossRef] [PubMed] 
96. Neuwelt, A.J.; Nguyen, T.M.; Fu, R.; Bubalo, J.; Tyson, R.M.; Lacy, C.; Gahramanov, S.; Nasseri, M.; Barnes, P.D.; Neuwelt, E.A. Incidence of Pneumocystis jirovecii pneumonia after temozolomide for CNS malignancies without prophylaxis. CNS Oncol. 2014, 3, 267-273. [CrossRef] [PubMed]

97. Mehta, M.; Wen, P.; Nishikawa, R.; Reardon, D.; Peters, K. Critical review of the addition of tumor treating fields (TTFields) to the existing standard of care for newly diagnosed glioblastoma patients. Crit. Rev. Oncol. Hematol. 2017, 111, 60-65. [CrossRef]

98. Zhu, P.; Zhu, J.-J. Tumor treating fields: A novel and effective therapy for glioblastoma: Mechanism, efficacy, safety and future perspectives. Chin. Clin. Oncol. 2017, 6, 41. [CrossRef]

99. Magouliotis, D.E.; Asprodini, E.K.; Svokos, K.A.; Tasiopoulou, V.S.; Svokos, A.A.; Toms, S.A. Tumor-treating fields as a fourth treating modality for glioblastoma: A meta-analysis. Acta Neurochir. (Wien) 2018, 160, 1167-1174. [CrossRef]

100. Guzauskas, G.F.; Salzberg, M.; Wang, B.C. Estimated lifetime survival benefit of tumor treating fields and temozolomide for newly diagnosed glioblastoma patients. CNS Oncol. 2018. [CrossRef]

101. Roh, T.H.; Park, H.H.; Kang, S.-G.; Moon, J.H.; Kim, E.H.; Hong, C.-K.; Ahn, S.S.; Choi, H.J.; Cho, J.; Kim, S.H.; et al. Long-term outcomes of concomitant chemoradiotherapy with temozolomide for newly diagnosed glioblastoma patients. Medicine (Baltimore). 2017, 96, e7422. [CrossRef] [PubMed]

102. Mandel, J.J.; Yust-Katz, S.; Patel, A.J.; Cachia, D.; Liu, D.; Park, M.; Yuan, Y.; Kent, T.A.; de Groot, J.F. Inability of positive phase II clinical trials of investigational treatments to subsequently predict positive phase III clinical trials in glioblastoma. Neuro Oncol. 2018, 20, 113-122. [CrossRef] [PubMed]

103. Mandel, J.J.; Youssef, M.; Ludmir, E.; Yust-Katz, S.; Patel, A.J.; De Groot, J.F. Highlighting the need for reliable clinical trials in glioblastoma. Expert Rev. Anticancer Ther. 2018, 18, 1031-1040. [CrossRef] [PubMed]

104. Weller, M.; Butowski, N.; Tran, D.D.; Recht, L.D.; Lim, M.; Hirte, H.; Ashby, L.; Mechtler, L.; Goldlust, S.A.; Iwamoto, F.; et al. Go, no-go decision making for phase 3 clinical trials: ACT IV revisited-Authors' reply. Lancet Oncol. 2017, 18, e708. [CrossRef]

105. Nguyen, H.T.N.; Grogan, P.; Robins, H.I. Go, no-go decision making for phase 3 clinical trials: ACT IV revisited. Lancet Oncol. 2017, 18, e708. [CrossRef]

106. Vanderbeek, A.M.; Rahman, R.; Fell, G.; Ventz, S.; Chen, T.; Redd, R.; Parmigiani, G.; Cloughesy, T.F.; Wen, P.Y.; Trippa, L.; et al. The clinical trials landscape for glioblastoma: Is it adequate to develop new treatments? Neuro Oncol. 2018, 20, 1034-1043. [CrossRef]

107. Porter, K.R.; McCarthy, B.J.; Berbaum, M.L.; Davis, F.G. Conditional survival of all primary brain tumor patients by age, behavior, and histology. Neuroepidemiology 2011, 36, 230-239. [CrossRef]

108. Darefsky, A.S.; King, J.T.; Dubrow, R. Adult glioblastoma multiforme survival in the temozolomide era: A population-based analysis of Surveillance, Epidemiology, and End Results registries. Cancer 2012, 118, 2163-2172. [CrossRef]

109. Ostrom, Q.T.; Gittleman, H.; Liao, P.; Rouse, C.; Chen, Y.; Dowling, J.; Wolinsky, Y.; Kruchko, C.; Barnholtz-Sloan, J. CBTRUS Statistical Report: Primary Brain and Central Nervous System Tumors Diagnosed in the United States in 2007-2011. Neuro Oncol. 2014, 16, iv1-iv63. [CrossRef]

110. Tykocki, T.; Eltayeb, M. Ten-year survival in glioblastoma. A systematic review. J. Clin. Neurosci. 2018, 54, 7-13. [CrossRef]

111. Cihoric, N.; Tsikkinis, A.; Minniti, G.; Lagerwaard, F.J.; Herrlinger, U.; Mathier, E.; Soldatovic, I.; Jeremic, B.; Ghadjar, P.; Elicin, O.; et al. Current status and perspectives of interventional clinical trials for glioblastoma-Analysis of ClinicalTrials.gov. Radiat. Oncol. 2017, 12. [CrossRef] [PubMed]

112. Dos Santos, M.A.; Pignon, J.-P.; Blanchard, P.; Lefeuvre, D.; Levy, A.; Touat, M.; Louvel, G.; Dhermain, F.; Soria, J.-C.; Deutsch, E.; et al. Systematic review and meta-analysis of phase I/II targeted therapy combined with radiotherapy in patients with glioblastoma multiforme: Quality of report, toxicity, and survival. J. Neurooncol. 2015, 123, 307-314. [CrossRef] [PubMed]

113. Su, J.; Cai, M.; Li, W.; Hou, B.; He, H.; Ling, C.; Huang, T.; Liu, H.; Guo, Y. Molecularly Targeted Drugs Plus Radiotherapy and Temozolomide Treatment for Newly Diagnosed Glioblastoma: A Meta-Analysis and Systematic Review. Oncol. Res. Featur. Preclin. Clin. Cancer Ther. 2016, 24, 117-128. [CrossRef] [PubMed]

114. Sim, H.-W.; Morgan, E.R.; Mason, W.P. Contemporary management of high-grade gliomas. CNS Oncol. 2018, 7, 51-65. [CrossRef] [PubMed]

115. Yin, A.; Cheng, J.; Zhang, X.; Liu, B. The treatment of glioblastomas: A systematic update on clinical Phase III trials. Crit. Rev. Oncol. Hematol. 2013, 87, 265-282. [CrossRef] [PubMed] 
116. Guishard, A.F.; Yakisich, J.S.; Azad, N.; Iyer, A.K.V. Translational gap in ongoing clinical trials for glioma. J. Clin. Neurosci. 2018, 47, 28-42. [CrossRef] [PubMed]

117. Alexander, B.M.; Trippa, L.; Gaffey, S.C.; Arrillaga, I.; Lee, E.Q.; Tanguturi, S.K.; Ahluwalia, M.S.; Colman, H.; Galanis, E.; De Groot, J.F.; et al. Individualized screening trial of innovative glioblastoma therapy (INSIGhT). J. Clin. Oncol. 2017, 35, TPS2079. [CrossRef]

118. Prasad, V. Perspective: The precision-oncology illusion. Nature 2016, 537, S63. [CrossRef]

119. Joyner, M.J.; Paneth, N.; Ioannidis, J.P.A. What Happens When Underperforming Big Ideas in Research Become Entrenched? JAMA 2016, 316, 1355-1356. [CrossRef]

120. Tannock, I.F.; Hickman, J.A. Limits to Personalized Cancer Medicine. N. Engl. J. Med. 2016, 375, $1289-1294$. [CrossRef]

121. Massard, C.; Michiels, S.; Ferté, C.; Le Deley, M.-C.; Lacroix, L.; Hollebecque, A.; Verlingue, L.; Ileana, E.; Rosellini, S.; Ammari, S.; et al. High-Throughput Genomics and Clinical Outcome in Hard-to-Treat Advanced Cancers: Results of the MOSCATO 01 Trial. Cancer Discov. 2017, 7, 586-595. [CrossRef] [PubMed]

122. Le Tourneau, C.; Delord, J.-P.; Gonçalves, A.; Gavoille, C.; Dubot, C.; Isambert, N.; Campone, M.; Trédan, O.; Massiani, M.-A.; Mauborgne, C.; et al. Molecularly targeted therapy based on tumour molecular profiling versus conventional therapy for advanced cancer (SHIVA): A multicentre, open-label, proof-of-concept, randomised, controlled phase 2 trial. Lancet Oncol. 2015, 16, 1324-1334. [CrossRef]

123. Wirsching, H.-G.; Tabatabai, G.; Roelcke, U.; Hottinger, A.F.; Jörger, F.; Schmid, A.; Plasswilm, L.; Schrimpf, D.; Mancao, C.; Capper, D.; et al. Bevacizumab plus hypofractionated radiotherapy versus radiotherapy alone in elderly patients with glioblastoma: The randomized, open-label, phase II ARTE trial. Ann. Oncol. 2018, 29, 1423-1430. [CrossRef] [PubMed]

124. Lombardi, G.; Pambuku, A.; Bellu, L.; Farina, M.; Della Puppa, A.; Denaro, L.; Zagonel, V. Effectiveness of antiangiogenic drugs in glioblastoma patients: A systematic review and meta-analysis of randomized clinical trials. Crit. Rev. Oncol. Hematol. 2017, 111, 94-102. [CrossRef] [PubMed]

125. Song, J.; Xue, Y.-Q.; Zhao, M.-M.; Xu, P. Effectiveness of lomustine and bevacizumab in progressive glioblastoma: A meta-analysis. Onco. Targets Ther. 2018, 11, 3435-3439. [CrossRef] [PubMed]

126. Taal, W.; Oosterkamp, H.M.; Walenkamp, A.M.E.; Dubbink, H.J.; Beerepoot, L.V.; Hanse, M.C.J.; Buter, J.; Honkoop, A.H.; Boerman, D.; de Vos, F.Y.F.; et al. Single-agent bevacizumab or lomustine versus a combination of bevacizumab plus lomustine in patients with recurrent glioblastoma (BELOB trial): A randomised controlled phase 2 trial. Lancet Oncol. 2014, 15, 943-953. [CrossRef]

127. Kim, M.M.; Umemura, Y.; Leung, D. Bevacizumab and Glioblastoma. Cancer J. 2018, 24, 180-186. [CrossRef]

128. Chen, Z.; Xu, N.; Zhao, C.; Xue, T.; Wu, X.; Wang, Z. Bevacizumab combined with chemotherapy vs single-agent therapy in recurrent glioblastoma: Evidence from randomized controlled trials. Cancer Manag. Res. 2018, 10, 2193-2205. [CrossRef] [PubMed]

129. Van den Bent, M.J.; Klein, M.; Smits, M.; Reijneveld, J.C.; French, P.J.; Clement, P.; de Vos, F.Y.F.; Wick, A.; Mulholland, P.J.; Taphoorn, M.J.B.; et al. Bevacizumab and temozolomide in patients with first recurrence of WHO grade II and III glioma, without $1 \mathrm{p} / 19 \mathrm{q}$ co-deletion (TAVAREC): A randomised controlled phase 2 EORTC trial. Lancet Oncol. 2018, 19, 1170-1179. [CrossRef]

130. Yazici, G.; Cengiz, M.; Ozyigit, G.; Eren, G.; Yildiz, F.; Akyol, F.; Gurkaynak, M.; Zorlu, F. Hypofractionated stereotactic reirradiation for recurrent glioblastoma. J. Neurooncol. 2014, 120, 117-123. [CrossRef]

131. Fogh, S.E.; Andrews, D.W.; Glass, J.; Curran, W.; Glass, C.; Champ, C.; Evans, J.J.; Hyslop, T.; Pequignot, E.; Downes, B.; et al. Hypofractionated Stereotactic Radiation Therapy: An Effective Therapy for Recurrent High-Grade Gliomas. J. Clin. Oncol. 2010, 28, 3048-3053. [CrossRef] [PubMed]

132. Ciammella, P.; Podgornii, A.; Galeandro, M.; D’Abbiero, N.; Pisanello, A.; Botti, A.; Cagni, E.; Iori, M.; Iotti, C. Hypofractionated stereotactic radiation therapy for recurrent glioblastoma: Single institutional experience. Radiat. Oncol. 2013, 8, 222. [CrossRef] [PubMed]

133. Fokas, E.; Wacker, U.; Gross, M.W.; Henzel, M.; Encheva, E.; Engenhart-Cabillic, R. Hypofractionated Stereotactic Reirradiation of Recurrent Glioblastomas. Strahlenther. Onkol. 2009, 185, 235-240. [CrossRef] [PubMed]

134. Wick, W.; Fricke, H.; Junge, K.; Kobyakov, G.; Martens, T.; Heese, O.; Wiestler, B.; Schliesser, M.G.; von Deimling, A.; Pichler, J.; et al. A Phase II, Randomized, Study of Weekly APG101+Reirradiation versus Reirradiation in Progressive Glioblastoma. Clin. Cancer Res. 2014, 20, 6304-6313. [CrossRef] [PubMed] 
135. Palmer, J.D.; Bhamidipati, D.; Song, A.; Eldredge-Hindy, H.B.; Siglin, J.; Dan, T.D.; Champ, C.E.; Zhang, I.; Bar-Ad, V.; Kim, L.; et al. Bevacizumab and re-irradiation for recurrent high grade gliomas: Does sequence matter? J. Neurooncol. 2018. [CrossRef] [PubMed]

136. Filley, A.C.; Henriquez, M.; Dey, M. Recurrent glioma clinical trial, CheckMate-143: The game is not over yet. Oncotarget 2017, 8, 91779-91794. [CrossRef]

137. Wilcox, J.A.; Ramakrishna, R.; Magge, R. Immunotherapy in Glioblastoma. World Neurosurg. 2018, 116, 518-528. [CrossRef]

138. Yarchoan, M.; Hopkins, A.; Jaffee, E.M. Tumor Mutational Burden and Response Rate to PD-1 Inhibition. N. Engl. J. Med. 2017, 377, 2500-2501. [CrossRef]

139. Naboush, A.; Roman, C.A.J.; Shapira, I. Immune checkpoint inhibitors in malignancies with mismatch repair deficiency: A review of the state of the current knowledge. J. Investig. Med. 2017, 65, 754-758. [CrossRef]

140. Mouw, K.W.; Goldberg, M.S.; Konstantinopoulos, P.A.; D’Andrea, A.D. DNA Damage and Repair Biomarkers of Immunotherapy Response. Cancer Discov. 2017, 7, 675-693. [CrossRef]

141. Viale, G.; Trapani, D.; Curigliano, G. Mismatch Repair Deficiency as a Predictive Biomarker for Immunotherapy Efficacy. Biomed. Res. Int. 2017, 2017, 1-7. [CrossRef] [PubMed]

142. Johanns, T.M.; Miller, C.A.; Dorward, I.G.; Tsien, C.; Chang, E.; Perry, A.; Uppaluri, R.; Ferguson, C.; Schmidt, R.E.; Dahiya, S.; et al. Immunogenomics of Hypermutated Glioblastoma: A Patient with Germline POLE Deficiency Treated with Checkpoint Blockade Immunotherapy. Cancer Discov. 2016, 6, 1230-1236. [CrossRef] [PubMed]

143. Bouffet, E.; Larouche, V.; Campbell, B.B.; Merico, D.; de Borja, R.; Aronson, M.; Durno, C.; Krueger, J.; Cabric, V.; Ramaswamy, V.; et al. Immune Checkpoint Inhibition for Hypermutant Glioblastoma Multiforme Resulting From Germline Biallelic Mismatch Repair Deficiency. J. Clin. Oncol. 2016, 34, 2206-2211. [CrossRef] [PubMed]

144. Hodges, T.R.; Ott, M.; Xiu, J.; Gatalica, Z.; Swensen, J.; Zhou, S.; Huse, J.T.; de Groot, J.; Li, S.; Overwijk, W.W.; et al. Mutational burden, immune checkpoint expression, and mismatch repair in glioma: Implications for immune checkpoint immunotherapy. Neuro Oncol. 2017, 19, 1047-1057. [CrossRef] [PubMed]

145. Wang, X.; Zhao, H.-Y.; Zhang, F.-C.; Sun, Y.; Xiong, Z.-Y.; Jiang, X.-B. Dendritic Cell-Based Vaccine for the Treatment of Malignant Glioma: A Systematic Review. Cancer Investig. 2014, 32, 451-457. [CrossRef] [PubMed]

146. Cao, J.-X.; Zhang, X.-Y.; Liu, J.-L.; Li, D.; Li, J.-L.; Liu, Y.-S.; Wang, M.; Xu, B.-L.; Wang, H.-B.; Wang, Z.-X. Clinical efficacy of tumor antigen-pulsed DC treatment for high-grade glioma patients: Evidence from a meta-analysis. PLoS ONE 2014, 9, e107173. [CrossRef] [PubMed]

147. Artene, S.-A.; Turcu-Stiolica, A.; Ciurea, M.E.; Folcuti, C.; Tataranu, L.G.; Alexandru, O.; Purcaru, O.S.; Tache, D.E.; Boldeanu, M.V.; Silosi, C.; et al. Comparative effect of immunotherapy and standard therapy in patients with high grade glioma: A meta-analysis of published clinical trials. Sci. Rep. 2018, 8, 11800. [CrossRef] [PubMed]

148. Hanaei, S.; Afshari, K.; Hirbod-Mobarakeh, A.; Mohajer, B.; Amir Dastmalchi, D.; Rezaei, N. Therapeutic efficacy of specific immunotherapy for glioma: A systematic review and meta-analysis. Rev. Neurosci. 2018, 29, 443-461. [CrossRef]

149. Sokratous, G.; Polyzoidis, S.; Ashkan, K. Immune infiltration of tumor microenvironment following immunotherapy for glioblastoma multiforme. Hum. Vaccin. Immunother. 2017, 13, 2575-2582. [CrossRef]

150. Wick, W.; van den Bent, M.J. First results on the DCVax phase III trial: Raising more questions than providing answers. Neuro Oncol. 2018, 20, 1283-1284. [CrossRef]

151. Sampson, J.H.; Aldape, K.D.; Archer, G.E.; Coan, A.; Desjardins, A.; Friedman, A.H.; Friedman, H.S.; Gilbert, M.R.; Herndon, J.E.; McLendon, R.E.; et al. Greater chemotherapy-induced lymphopenia enhances tumor-specific immune responses that eliminate EGFRvIII-expressing tumor cells in patients with glioblastoma. Neuro Oncol. 2011, 13, 324-333. [CrossRef]

152. Schuster, J.; Lai, R.K.; Recht, L.D.; Reardon, D.A.; Paleologos, N.A.; Groves, M.D.; Mrugala, M.M.; Jensen, R.; Baehring, J.M.; Sloan, A.; et al. A phase II, multicenter trial of rindopepimut (CDX-110) in newly diagnosed glioblastoma: The ACT III study. Neuro Oncol. 2015, 17, 854-861. [CrossRef] [PubMed]

153. Reardon, D.A.; Desjardins, A.; Schuster, J.; Tran, D.D.; Fink, K.L.; Nabors, L.B.; Li, G.; Bota, D.A.; Lukas, R.V.; Ashby, L.S.; et al. IMCT-08ReACT: long-term survival from a randomized phase ii study of rindopepimut (CDX-110) plus bevacizumab in relapsed glioblastoma. Neuro Oncol. 2015, 17. [CrossRef] 
154. Wen, P.; Reardon, D.; Phuphanich, S.; Aiken, R.; Landolfi, J.; Curry, W.; Zhu, J.-J.; Glantz, M.; Peereboom, D.; Markert, J.; et al. A randomized, double-blind, placebo-controlled phase 2 trial of dendritic cell (DC) vaccination with ICT-107 in newly diagnosed glioblastoma (GBM) patients. J. Clin. Oncol. 2014, 32, 2005.

155. Buchroithner, J.; Erhart, F.; Pichler, J.; Widhalm, G.; Preusser, M.; Stockhammer, G.; Nowosielski, M.; Iglseder, S.; Freyschlag, C.; Oberndorfer, S.; et al. Audencel Immunotherapy Based on Dendritic Cells Has No Effect on Overall and Progression-Free Survival in Newly Diagnosed Glioblastoma: A Phase II Randomized Trial. Cancers 2018, 10, 372. [CrossRef] [PubMed]

156. Cho, D.-Y.; Yang, W.-K.; Lee, H.-C.; Hsu, D.-M.; Lin, H.-L.; Lin, S.-Z.; Chen, C.-C.; Harn, H.-J.; Liu, C.-L.; Lee, W.-Y.; et al. Adjuvant immunotherapy with whole-cell lysate dendritic cells vaccine for glioblastoma multiforme: A phase II clinical trial. World Neurosurg. 2012, 77, 736-744. [CrossRef] [PubMed]

157. Inogés, S.; Tejada, S.; de Cerio, A.L.-D.; Gállego Pérez-Larraya, J.; Espinós, J.; Idoate, M.A.; Domínguez, P.D.; de Eulate, R.G.; Aristu, J.; Bendandi, M.; et al. A phase II trial of autologous dendritic cell vaccination and radiochemotherapy following fluorescence-guided surgery in newly diagnosed glioblastoma patients. J. Transl. Med. 2017, 15, 104. [CrossRef]

158. Yao, Y.; Luo, F.; Tang, C.; Chen, D.; Qin, Z.; Hua, W.; Xu, M.; Zhong, P.; Yu, S.; Chen, D.; et al. Molecular subgroups and B7-H4 expression levels predict responses to dendritic cell vaccines in glioblastoma: An exploratory randomized phase II clinical trial. Cancer Immunol. Immunother. 2018. [CrossRef]

159. Bota, D.A.; Chung, J.; Dandekar, M.; Carrillo, J.A.; Kong, X.-T.; Fu, B.D.; Hsu, F.P.; Schönthal, A.H.; Hofman, F.M.; Chen, T.C.; et al. Phase II study of ERC1671 plus bevacizumab versus bevacizumab plus placebo in recurrent glioblastoma: Interim results and correlations with CD4 ${ }^{+}$T-lymphocyte counts. CNS Oncol. 2018, cns-2018-0009. [CrossRef]

160. Dillman, R.O.; Duma, C.M.; Ellis, R.A.; Cornforth, A.N.; Schiltz, P.M.; Sharp, S.L.; DePriest, M.C. Intralesional lymphokine-activated killer cells as adjuvant therapy for primary glioblastoma. J. Immunother. 2009, 32, 914-919. [CrossRef]

161. Dutoit, V.; Migliorini, D.; Patrikidou, A.; Mayer-Mokler, A.; Hilf, N.; Walker, P.R.; Dietrich, P.-Y. IMA950 multipeptide vaccine adjuvanted with poly-ICLC in combination with standard therapy in newly diagnosed HLA-A2 glioblastoma patients. Ann. Oncol. 2017, 28, B148. [CrossRef]

162. Prins, R.M.; Soto, H.; Konkankit, V.; Odesa, S.K.; Eskin, A.; Yong, W.H.; Nelson, S.F.; Liau, L.M. Gene Expression Profile Correlates with T-Cell Infiltration and Relative Survival in Glioblastoma Patients Vaccinated with Dendritic Cell Immunotherapy. Clin. Cancer Res. 2011, 17, 1603-1615. [CrossRef] [PubMed]

163. Jie, X.; Hua, L.; Jiang, W.; Feng, F.; Feng, G.; Hua, Z. Clinical application of a dendritic cell vaccine raised against heat-shocked glioblastoma. Cell Biochem. Biophys. 2012, 62, 91-99. [CrossRef] [PubMed]

164. Vik-Mo, E.O.; Nyakas, M.; Mikkelsen, B.V.; Moe, M.C.; Due-Tønnesen, P.; Suso, E.M.I.; Sæbøe-Larssen, S.; Sandberg, C.; Brinchmann, J.E.; Helseth, E.; et al. Therapeutic vaccination against autologous cancer stem cells with mRNA-transfected dendritic cells in patients with glioblastoma. Cancer Immunol. Immunother. 2013, 62, 1499-1509. [CrossRef]

165. Ardon, H.; Van Gool, S.W.; Verschuere, T.; Maes, W.; Fieuws, S.; Sciot, R.; Wilms, G.; Demaerel, P.; Goffin, J.; Van Calenbergh, F; i et al. Integration of autologous dendritic cell-based immunotherapy in the standard of care treatment for patients with newly diagnosed glioblastoma: Results of the HGG-2006 phase I/II trial. Cancer Immunol. Immunother. 2012, 61, 2033-2044. [CrossRef] [PubMed]

166. Yamanaka, R.; Homma, J.; Yajima, N.; Tsuchiya, N.; Sano, M.; Kobayashi, T.; Yoshida, S.; Abe, T.; Narita, M.; Takahashi, M.; et al. Clinical evaluation of dendritic cell vaccination for patients with recurrent glioma: Results of a clinical phase I/II trial. Clin. Cancer Res. 2005, 11, 4160-4167. [CrossRef] [PubMed]

167. De Vleeschouwer, S.; Fieuws, S.; Rutkowski, S.; Van Calenbergh, F.; Van Loon, J.; Goffin, J.; Sciot, R.; Wilms, G.; Demaerel, P.; Warmuth-Metz, M.; et al. Postoperative Adjuvant Dendritic Cell-Based Immunotherapy in Patients with Relapsed Glioblastoma Multiforme. Clin. Cancer Res. 2008, 14, 3098-3104. [CrossRef]

168. Brown, C.E.; Alizadeh, D.; Starr, R.; Weng, L.; Wagner, J.R.; Naranjo, A.; Ostberg, J.R.; Blanchard, M.S.; Kilpatrick, J.; Simpson, J.; et al. Regression of Glioblastoma after Chimeric Antigen Receptor T-Cell Therapy. N. Engl. J. Med. 2016, 375, 2561-2569. [CrossRef]

169. O’Rourke, D.M.; Nasrallah, M.P.; Desai, A.; Melenhorst, J.J.; Mansfield, K.; Morrissette, J.J.D.; Martinez-Lage, M.; Brem, S.; Maloney, E.; Shen, A.; et al. A single dose of peripherally infused EGFRvIII-directed CAR T cells mediates antigen loss and induces adaptive resistance in patients with recurrent glioblastoma. Sci. Transl. Med. 2017, 9, eaaa0984. [CrossRef] 
170. Ahmed, N.; Brawley, V.; Hegde, M.; Bielamowicz, K.; Kalra, M.; Landi, D.; Robertson, C.; Gray, T.L.; Diouf, O.; Wakefield, A.; et al. HER2-Specific Chimeric Antigen Receptor-Modified Virus-Specific T Cells for Progressive Glioblastoma. JAMA Oncol. 2017, 3, 1094. [CrossRef]

171. Migliorini, D.; Dietrich, P.-Y.; Stupp, R.; Linette, G.P.; Posey, A.D.; June, C.H. CAR T-Cell Therapies in Glioblastoma: A First Look. Clin. Cancer Res. 2018, 24, 535-540. [CrossRef] [PubMed]

172. Prinzing, B.L.; Gottschalk, S.M.; Krenciute, G. CAR T-cell therapy for glioblastoma: Ready for the next round of clinical testing? Expert Rev. Anticancer Ther. 2018, 18, 451-461. [CrossRef] [PubMed]

173. Eissa, I.; Bustos-Villalobos, I.; Ichinose, T.; Matsumura, S.; Naoe, Y.; Miyajima, N.; Morimoto, D.; Mukoyama, N.; Zhiwen, W.; Tanaka, M.; et al. The Current Status and Future Prospects of Oncolytic Viruses in Clinical Trials against Melanoma, Glioma, Pancreatic, and Breast Cancers. Cancers 2018, 10, 356. [CrossRef] [PubMed]

174. Fueyo, J.; Alemany, R.; Gomez-Manzano, C.; Fuller, G.N.; Khan, A.; Conrad, C.A.; Liu, T.-J.; Jiang, H.; Lemoine, M.G.; Suzuki, K.; et al. Preclinical characterization of the antiglioma activity of a tropism-enhanced adenovirus targeted to the retinoblastoma pathway. J. Natl. Cancer Inst. 2003, 95, 652-660. [CrossRef] [PubMed]

175. Lang, F.F.; Tran, N.D.; Puduvalli, V.K.; Elder, J.B.; Fink, K.L.; Conrad, C.A.; Yung, W.K.A.; Penas-Prado, M.; Gomez-Manzano, C.; Peterkin, J.; et al. Phase 1b open-label randomized study of the oncolytic adenovirus DNX-2401 administered with or without interferon gamma for recurrent glioblastoma. J. Clin. Oncol. 2017, 35, 2002. [CrossRef]

176. Chiocca, E.A.; Yu, J.; Phuphanich, S.; Lukas, R.V.; Kumthekar, P.; Yang, Y.; Zhou, Q.; Buck, J.Y.; Deary, A.; Cai, H.; Barrett, J.A.; et al. Expanded phase I study of intratumoral Ad-RTS-hIL-12 plus oral veledimex: Tolerability and survival in recurrent glioblastoma. J. Clin. Oncol. 2017, 35, 2044. [CrossRef]

177. Chiocca, E.A.; Nassiri, F.; Wang, J.; Peruzzi, P.; Zadeh, G. Viral and other therapies for recurrent GBM: Is a 24-month durable response unusual? Neuro Oncol. 2018. [CrossRef]

178. Rudra, S.; Hui, C.; Rao, Y.J.; Samson, P.; Lin, A.J.; Chang, X.; Tsien, C.; Fergus, S.; Mullen, D.; Yang, D.; et al. Effect of Radiation Treatment Volume Reduction on Lymphopenia in Patients Receiving Chemoradiotherapy for Glioblastoma. Int. J. Radiat. Oncol. Biol. Phys. 2018, 101, 217-225. [CrossRef]

179. Ellsworth, S.G. Field size effects on the risk and severity of treatment-induced lymphopenia in patients undergoing radiation therapy for solid tumors. Adv. Radiat. Oncol. 2018, 3, 512-519. [CrossRef]

180. Yovino, S.; Kleinberg, L.; Grossman, S.A.; Narayanan, M.; Ford, E. The Etiology of Treatment-related Lymphopenia in Patients with Malignant Gliomas: Modeling Radiation Dose to Circulating Lymphocytes Explains Clinical Observations and Suggests Methods of Modifying the Impact of Radiation on Immune Cells. Cancer Investig. 2013, 31. [CrossRef]

181. Gupta, T.; Mohanty, S.; Moiyadi, A.; Jalali, R. Factors predicting temozolomide induced clinically significant acute hematologic toxicity in patients with high-grade gliomas: A clinical audit. Clin. Neurol. Neurosurg. 2013, 115, 1814-1819. [CrossRef] [PubMed]

182. Ishikawa, E.; Yamamoto, T.; Sakamoto, N.; Nakai, K.; Akutsu, H.; Tsuboi, K.; Takano, S.; Matsumura, A. Low peripheral lymphocyte count before focal radiotherapy plus concomitant temozolomide predicts severe lymphopenia during malignant glioma treatment. Neurol. Med. Chir. (Tokyo) 2010, 50, 638-644. [CrossRef] [PubMed]

183. Gerber, D.E.; Grossman, S.A.; Zeltzman, M.; Parisi, M.A.; Kleinberg, L. The impact of thrombocytopenia from temozolomide and radiation in newly diagnosed adults with high-grade gliomas1. Neuro Oncol. 2007, 9, 47-52. [CrossRef] [PubMed]

184. Mendez, J.S.; Govindan, A.; Leong, J.; Gao, F.; Huang, J.; Campian, J.L. Association between treatment-related lymphopenia and overall survival in elderly patients with newly diagnosed glioblastoma. J. Neurooncol. 2016, 127, 329-335. [CrossRef] [PubMed]

185. Rahman, R.; Catalano, P.J.; Arvold, N.D.; Aizer, A.A.; Weiss, S.E.; Pinnell, N.; Horvath, M.C.; Christianson, L.; Reardon, D.A.; Lee, E.Q.; et al. Chemoradiation-Related Lymphopenia Is Common Among Glioblastoma Patients and Is Associated with Worse Progression-Free and Overall Survival. Int. J. Radiat. Oncol. 2016, 96, E123. [CrossRef]

186. Mariucci, S.; Rovati, B.; Manzoni, M.; Della Porta, M.G.; Comolli, G.; Delfanti, S.; Danova, M. Lymphocyte subpopulation and dendritic cell phenotyping during antineoplastic therapy in human solid tumors. Clin. Exp. Med. 2011, 11, 199-210. [CrossRef] 
187. Sengupta, S.; Marrinan, J.; Frishman, C.; Sampath, P. Impact of temozolomide on immune response during malignant glioma chemotherapy. Clin. Dev. Immunol. 2012, 2012, 831090. [CrossRef]

188. Hsu, M.; Sedighim, S.; Wang, T.; Antonios, J.P.; Everson, R.G.; Tucker, A.M.; Du, L.; Emerson, R.; Yusko, E.; Sanders, C.; et al. TCR Sequencing Can Identify and Track Glioma-Infiltrating T Cells after DC Vaccination. Cancer Immunol. Res. 2016, 4, 412-418. [CrossRef]

189. Tysome, J.R.; Li, X.; Wang, S.; Wang, P.; Gao, D.; Du, P.; Chen, D.; Gangeswaran, R.; Chard, L.S.; Yuan, M.; et al. A novel therapeutic regimen to eradicate established solid tumors with an effective induction of tumor-specific immunity. Clin. Cancer Res. 2012, 18, 6679-6689. [CrossRef]

190. Wang, P.; Li, X.; Wang, J.; Gao, D.; Li, Y.; Li, H.; Chu, Y.; Zhang, Z.; Liu, H.; Jiang, G.; et al. Re-designing Interleukin-12 to enhance its safety and potential as an anti-tumor immunotherapeutic agent. Nat. Commun. 2017, 8, 1395. [CrossRef]

191. Kleijn, A.; van den Bossche, W.; Haefner, E.S.; Belcaid, Z.; Burghoorn-Maas, C.; Kloezeman, J.J.; Pas, S.D.; Leenstra, S.; Debets, R.; de Vrij, J.; et al. The Sequence of Delta24-RGD and TMZ Administration in Malignant Glioma Affects the Role of CD8(+)T Cell Anti-tumor Activity. Mol. Ther. Oncol. 2017, 5, 11-19. [CrossRef] [PubMed]

192. Koks, C.A.; Garg, A.D.; Ehrhardt, M.; Riva, M.; Vandenberk, L.; Boon, L.; De Vleeschouwer, S.; Agostinis, P.; Graf, N.; Van Gool, S.W. Newcastle disease virotherapy induces long-term survival and tumor-specific immune memory in orthotopic glioma through the induction of immunogenic cell death. Int. J. Cancer 2015, 136, E313-E325. [CrossRef] [PubMed]

193. Saha, D.; Martuza, R.L.; Rabkin, S.D. Macrophage Polarization Contributes to Glioblastoma Eradication by Combination Immunovirotherapy and Immune Checkpoint Blockade. Cancer Cell 2017, 32, $253-267$. [CrossRef] [PubMed]

194. Fritzell, S.; Sandén, E.; Eberstål, S.; Visse, E.; Darabi, A.; Siesjö, P. Intratumoral temozolomide synergizes with immunotherapy in a T cell-dependent fashion. Cancer Immunol. Immunother. 2013, 62, 1463-1474. [CrossRef] [PubMed]

195. Curtin, J.F.; Liu, N.; Candolfi, M.; Xiong, W.; Assi, H.; Yagiz, K.; Edwards, M.R.; Michelsen, K.S.; Kroeger, K.M.; Liu, C.; et al. HMGB1 mediates endogenous TLR2 activation and brain tumor regression. PLoS Med. 2009, 6, e10. [CrossRef] [PubMed]

196. Curtin, J.F.; Candolfi, M.; Fakhouri, T.M.; Liu, C.; Alden, A.; Edwards, M.; Lowenstein, P.R.; Castro, M.G. Treg depletion inhibits efficacy of cancer immunotherapy: Implications for clinical trials. PLoS ONE 2008, 3, e1983. [CrossRef] [PubMed]

197. Li, X.; Wang, P.; Li, H.; Du, X.; Liu, M.; Huang, Q.; Wang, Y.; Wang, S. The Efficacy of Oncolytic Adenovirus Is Mediated by T-cell Responses against Virus and Tumor in Syrian Hamster Model. Clin. Cancer Res. 2017, 23, 239-249. [CrossRef]

198. Pellegatta, S.; Eoli, M.; Cuccarini, V.; Anghileri, E.; Pollo, B.; Pessina, S.; Frigerio, S.; Servida, M.; Cuppini, L.; Antozzi, C.; et al. Survival gain in glioblastoma patients treated with dendritic cell immunotherapy is associated with increased NK but not CD8+ T cell activation in the presence of adjuvant temozolomide. Oncoimmunology 2018, 7, e1412901. [CrossRef]

199. Fadul, C.E.; Fisher, J.L.; Gui, J.; Hampton, T.H.; Cote, A.L.; Ernstoff, M.S. Immune modulation effects of concomitant temozolomide and radiation therapy on peripheral blood mononuclear cells in patients with glioblastoma multiforme. Neuro Oncol. 2011, 13, 393-400. [CrossRef]

200. Ellsworth, S.; Balmanoukian, A.; Kos, F.; Nirschl, C.J.; Nirschl, T.R.; Grossman, S.A.; Luznik, L.; Drake, C.G. Sustained $\mathrm{CD}^{+}{ }^{+} \mathrm{T}$ cell-driven lymphopenia without a compensatory IL-7/IL-15 response among high-grade glioma patients treated with radiation and temozolomide. Oncoimmunology 2014, 3, e27357. [CrossRef]

(C) 2018 by the authors. Licensee MDPI, Basel, Switzerland. This article is an open access article distributed under the terms and conditions of the Creative Commons Attribution (CC BY) license (http:/ / creativecommons.org/licenses/by/4.0/). 